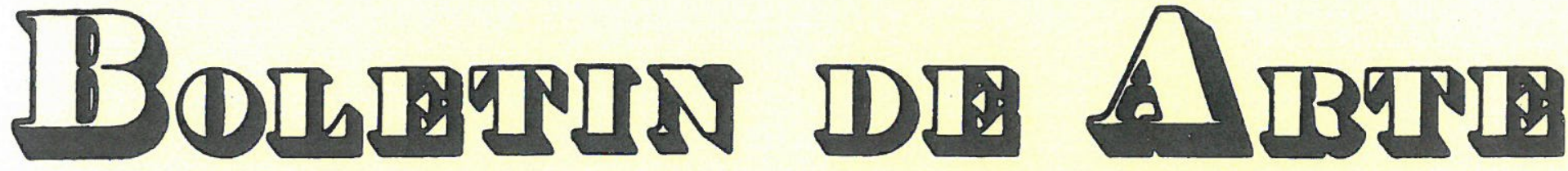

Núm. 20

1999

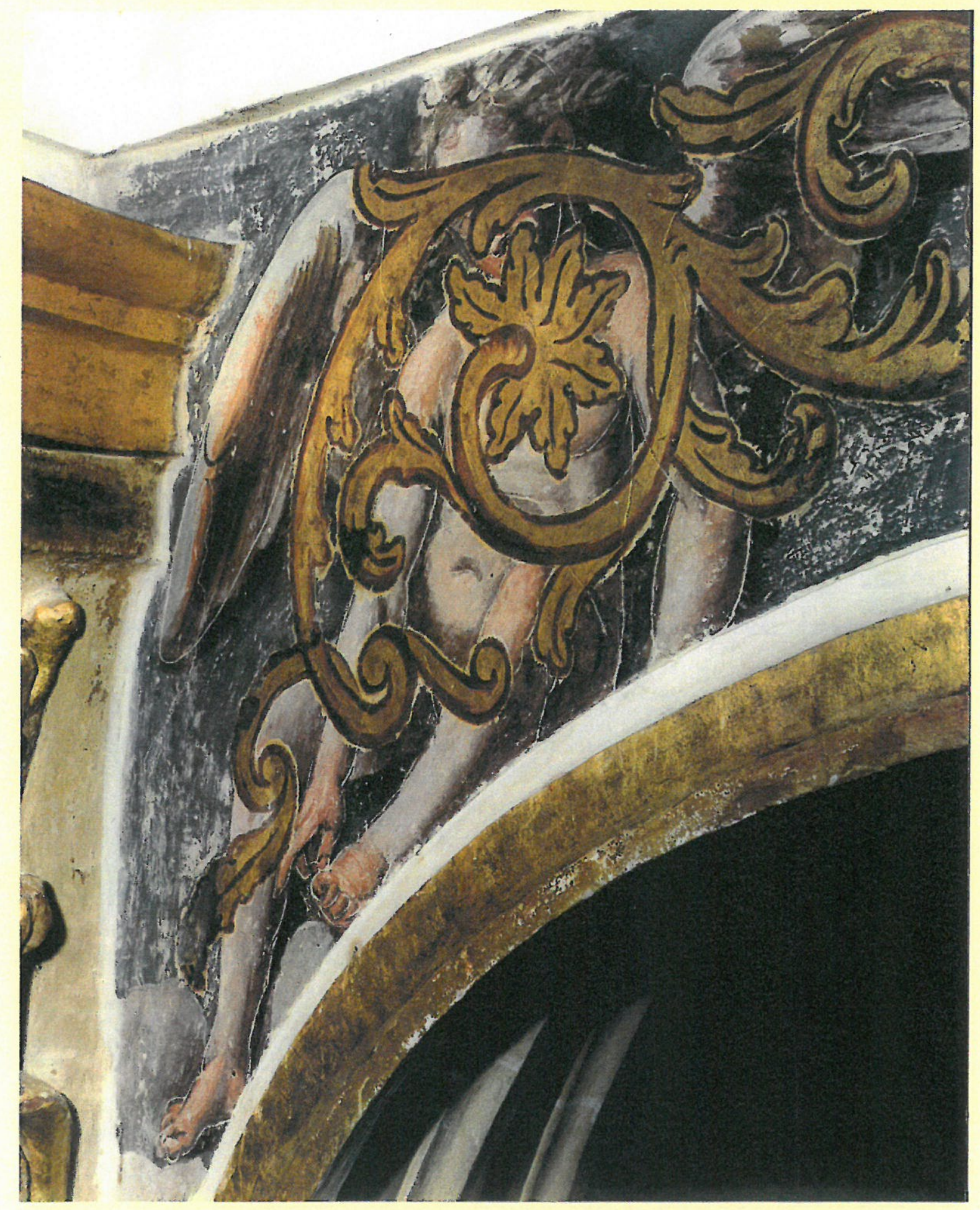

UNIVERSIDAD DE MALAGA

DEPARTAMENTO DE HISTORIA DEL ARTE 


\section{ARTíCULOS}

UNA TIPOLOGÍA URBANA: LA CALLE DE CABALLEROS EN ESPAÑA, por Antonio Bonet Correa

TEATROS DE NATURALEZA: ESCENARIOS PARA LOS DIOSES. ARTIFICIOS Y OTROS INGENIOS EN LOS JARDINES ESPAÑOLES DEL RENACIMIENTO AL BARROCO, por Carmen González Román

UNA LECTURA SIMBÓLICA DEL PLATERESCO SEGÚN EL PSICOANÁLISIS DE LA PERCEPCIÓN DE EHRENZWEIG, por César García Alvarez

EL MUNDO AL REVÉS. LECTURAS ICONOGRÁFICAS SOBRE UN GRABADO DE ANTON WIERIX CONTRA EL DOMINIO DE FELIPE, por Vicente Pla Vivas

SÍMBOLOS Y HERÁLDICA EN LOS EXPEDIENTES DE ÓRDENES MILITARES EN MURCIA DURANTE EL SIGLO XVI, por Francisco José García Pérezy Juan Hernández Franco

ESCULTORES Y PINTORES DEL CÍRCULO ANTEQUERANO DEL SIGLO XVI. APORTACIONES DOCUMENTALES, por José Escalante Jiménez

EL VENERABLE FERNANDO CONTRERAS, UN SANTO PARA LA CATEDRAL DE SEVILLA, por Fernando Quiles García

DIVERSIDAD PROFESIONAL EN LA CREACIÓN DEL RETABLO. EL CÁDIZ BARROCO, por Lorenzo Alonso de la Sierra Fernández.

FIESTA Y CEREMONIAL DE LAS CORTES DE GÉNOVA Y MADRID. LLEGADA Y CELEBRACIÓN DEL MATRIMONIO DE LA NUEVA PRINCESA DE ASTURIAS M ${ }^{\mathrm{a}}$ LUISA DE PARMA EN 1765, por Laura García Sánchez

LA REAL ACADEMIA DE SAN CARLOS: NEOCOLONIA ARTÍSTICA, por Tania García Lescaille 


\title{
ESCULTORES Y PINTORES DEL CÍRCULO ANTEQUERANO DEL SIGLO XVI. APORTACIONES DOCUMENTALES.
}

\author{
José Escalante Jiménez
}

\begin{abstract}
El siglo XVI marca el inicio de un esplendoroso florecimiento artístico en Antequera, que alcanza su máxima eclosión en el XVIII. El presente trabajo ofrece un prontuario documental que constata la existencia de un activo foco escultórico y pictórico en el Quinientos, alcanzando en sus creaciones unas cotas de calidad tan apreciables que motivaron, en su día, equivocadas atribuciones a artistas más conocidos.
\end{abstract}

Una de las asignaturas pendientes en la investigación histórica de nuestra provincia es sin duda la referida al ámbito artístico en la ciudad de Antequera, donde tan sólo el investigador José María Fernández y el historiador Jesús Romero Benítez han abordado de una forma científica y amplia este aspecto de la historia local. El importante desarrollo de las artes plásticas en el contexto de la ciudad de Antequera nos obliga a plantear su estudio por etapas. Así, con el presente trabajo abordaremos el siglo XVI en su ultimo cuarto, al ser el período en el que prácticamente se define este círculo artístico local.

Nuestro estudio no va referido a una valoración critica de las piezas u obras conservadas. Aquí tan sólo nos vamos a limitar a aportar una serie de datos referidos a información biográfica y productiva de una serie de artistas que hemos podido documentar, los cuales desarrollaron de una forma más o menos continua su labor teniendo como centro de trabajo la ciudad de Antequera.

A partir de la segunda mitad del siglo XVI Antequera se convirtió en un auténtico hervidero de artesanos y artistas de todas las facultades, atraídos por el auge económico, constructivo y cultural que vivía la ciudad. La Cátedra de Gramática de la Real Colegiata de Santa María la Mayor aglutinó durante esta época a sus más insignes y afamados preceptores, origen del grupo poético antequerano del siglo de oro. Se estaba construyendo la base de la Antequera culta, moderna y monumental. Además, una nueva ciudad surgía de las manos de algunos artífices de la piedra, como el vasco Francisco de Azurriola, o del alarife Francisco Gutiérrez Garrido, padre del manierismo arquitectónico antequerano, quien también trabajó en numerosos puntos de Andalucía. Toda esta plenitud creadora no estaría completa sin los entalladores, escultores, carpinteros de lo blanco, pintores y doradores.

Hasta hace escaso tiempo no había en Antequera un conocimiento claro de la existencia durante el Quinientos de un círculo de pintores y escultores locales o 
establecidos en la ciudad que tuvieran una identidad y un carácter propios. Es más, se desconocía su existencia. Esta circunstancia se ha debido a la falta de un estudio profundo y pormenorizado sobre el período al que nos referimos. Por regla general, la obra escultórica e imaginera de esta época, muy importante por otro lado, se ha venido adjudicando sistemáticamente a artistas de las escuelas sevillana o granadina.

Hoy día, aun con los pocos datos con que contamos, podemos hablar ya de la existencia de un importante circulo artístico local, que nace en la segunda mitad del XVI y se configura y define durante el último cuarto del referido siglo, y que estaría formado entre otros por los maestros de escultura Diego de Vega, Juan Vázquez de Vega, Andrés Iriarte, Juan de Montes, Baltasar López, Luis de Haya o Antonio de Osuna; pintores y policromadores como Antonio Mohedano de la Gutierra, José Hernández, Gabriel Ortiz, y no podemos dejar atrás a dos buenos ensambladores: Juan Marcos y Alonso Martín de Alamilla, entre otros muchos. Poco sabemos todavía de ellos, aunque los hallazgos realizados en el Archivo Histórico Municipal de nuestra ciudad nos auguran unos importantes resultados.

Seguidamente desarrollaremos una nomina de artistas, de los que aportaremos los datos biográficos y las obras documentadas que se han podido localizar hasta ahora, independientemente de si se conservan o no, evitando en la medida de lo posible realizar una valoración sobre las mismas, labor que creemos corresponde a otros.

\section{JUAN VÁZQUEZ DE VEGA}

Fue pintor, dorador y escultor, además de amigo de Antonio Mohedano de la Gutierra, con el que compartió algunos trabajos. La primera referencia documental que tenemos de este artista la encontramos en el tratado del Arte de la Pintura de Francisco Pacheco ${ }^{1}$ en el que se dice que tanto Juan Vázquez como Antonio Mohedano son dos grandes maestros de la pintura que iniciaron su oficio en la técnica de la sarga.

Las diversas historias manuscritas de la ciudad, tales como las de Francisco Barrero Baquerizo, la de Manuel Solana, la de Quirós de los Ríos o la del Padre Cabrera, en sus capítulos dedicados a personas que han florecido en las artes en nuestra ciudad, solamente nos dicen de Juan Vázquez de Vega que fue un excelentísimo pintor, pero no ofrecen dato alguno más, ni por supuesto hacen referencia a su faceta escultórica. Sin embargo ejerció ambos oficios. De las obras que hemos podido recopilar documentalmente hasta ahora y que perviven, cabe destacar la imagen de Nuestra Señora del Rosario del convento de Santo

\footnotetext{
'BASEGODA I HUGAS, B.: Edición, introducción y notas sobre el tratado de "Arte de la Pintura" de Francisco Pacheco. Madrid, 1990.
} 
Escultores y pintores del círculo antequerano del XVI. Aportaciones...

Domingo, una de las más veneradas advocaciones marianas de Antequera, que desde el siglo XVII cuenta con una masiva devoción por parte del pueblo. Se trata de una talla de bulto redondo, de aproximadamente $130 \mathrm{~cm}$. de altura, con un drapeado de paños muy clásico y ricamente estofado. Se representa erguida, sosteniendo en su mano izquierda al Salvador y el cetro en la derecha. Su rostro ofrece una gran serenidad $y$, en conjunto, podemos decir que es obra de gran delicadeza, que nos hace pensar en un primer momento en el estilo de Pablo de Rojas y su escuela.

Esta imagen, titular de la cofradía de su mismo nombre, está ubicada en la actualidad en el convento de Santo Domingo, aunque en origen procede del antiguo Hospital de la Caridad, donde realmente se fundó la cofradía, trasladándose sobre 1590 al referido convento. Estando ya en el Hospital de la Caridad, los hermanos de la cofradía contrataron con Juan Vázquez de Vega la hechura de la imagen que ha llegado a nuestros días. Dice el contrato en su parte fundamental:

En la muy noble ciudad de antequera veynte e uno dias del mes de nobiembre de myll e quinientos y ochenta e siete anos en presencia de my el escrivano publico e testigos de yuso escriptos juan Bazquez de bega pintor de imaxineria vezino desta ciudad al qual yo el dho scrivano doy fee que conozco e otorgo y convino que se obligava y se obligo de hazer una ymaxen de nuestra senora para los hermanos e cofradia del ospítal de la caridad de esta ciudad la qual hara de talla e dorado e pintura del tamaño de bara y media sin la peana que a de tener la qual hara de buena madera limpia e bien sazonada e que este hueca para que sepueda llebar en andas en procesion y a de ser dorada y estofada al rrededor porque por rrazon de la hechura e oro y madera e todo lo demas quea de llebar la dha ymaxen se le a de dar E pagar quarenta y ocho ducados... ${ }^{2}$

Las primeras referencias que tenemos hasta ahora sobre este pintor y escultor en Antequera se remontan a 1579. El 24 de junio de este año conviene, con doña María Cobo, el arriendo de una casa por tiempo de un año ${ }^{3}$. La importancia de este documento, aparte de ser el primero que conocemos cronológicamente del artista, radica en que actúa como su fiador y garante el maestro de cantería Francisco de Azurriola, que por aquellos años estaba trabajando para las Fábricas Mayores de la ciudad. Concretamente en 1578 le encargaron todos los basamentos del "Sagrario"

\footnotetext{
${ }^{2}$ Archivo Histórico Municipal de Antequera (A.H.M.A.) - Fondo de Protocolos Notariales (F.P.N.) Escribano: Gonzalo de León. Legajo 653, fols. 2.027r - 2.028v.

3 A.H.M.A. - F.P.N. Escribano: Cristóbal Méndez. Legajo 1.536, fols. 524 - 524v.
} 


\section{José Escalante Jiménez}

para la Real Colegiata de Santa María la Mayor ${ }^{4}$. Esta obra en su conjunto se compone de dos piezas: el tabernáculo o Sagrario propiamente dicho, diseñado y policromado por Antonio Mohedano de la Gutierra y ensamblado por los maestros Diego Maldonado y Juan Marcos 5 , y el baldaquino o ciborio, que es denominado en la Historia de Antequera del Padre Cabrera y en la de Manuel Solana como tabernáculo y nos lo describen de esta forma:

... un Tabernaculo de madera de quatro colunas doricas con sus Capiteles y pedestales sostenidas sobre cuatro pedestales de piedra colorada bruñidas y labradas, y sobre ellas acienta una Copula de media naranja toda dorada y pintada por dentro yfuera con sus remates las Columnas; su línterna, y sobre ella, una Cruz con un Crucifixo pintado en ella....

Esta aclaración es totalmente necesaria para poder llegar a interpretar en su amplitud el siguiente documento, firmado entre las Fábricas Mayores y Juan Vázquez de Vega:

En la ciudad de antequera en treynta días del mes de agosto de mill e quinientos ochenta años por ante mí el scrívano e testigos juan Vazquez pintor como principal deudor e francisco gutierrez de lepe alvañil como fiador e principal pagador vezinos desta dha ciudad de antequera... dixieron que por quanto el dho Juan Vazquez tiene de dorar e pintar el tabernaculo de la yglesia mayor desta dha ciudad e comofuere haziendo la dha obra se le tiene de yr pagando... ${ }^{6}$.

Este baldaquino que en la actualidad está instalado en la capilla mayor de la iglesia parroquial de San $\mathrm{Pedro}^{7}$, nos recuerda lejanamente al que diseñó el maestro Siloé para la catedral de Granada. La media naranja ochavada, en su parte externa, está policromada con grutescos en sus gajos; internamente se desarrollan los temas del Salvador, la Virgen, San Pedro, San Pablo y los cuatro Evangelistas, culminando en el centro con un Espíritu Santo. La cúpula, como se ha dicho, termina con una linterna rematada con una cruz, sobre la que hay pintado un Cristo.

Este es el primer documento que sobre la pintura de Juan Vázquez nos ha llegado, y es de gran importancia, ya que nos podrá servir de base para efectuar nuevas atribuciones en un futuro, a falta de otras obras documentadas.

${ }^{4}$ A.H.M.A. - F.P.N. Escribano: Gonzalo de León. Legajo 395, fols. 214v - 215 r.

5 LLORDÉN, A.: "El tabernáculo de la colegiata de Antequera", Jábega, 28. Málaga, 1979.

${ }^{6}$ A.H.M.A.- F.P.N. Escribano: Juan Pérez Berrio. Legajo 943, fols. 391v - 392r

7 PAREJO, A. y ROMERO, J.: "El baldaquino de la Colegiata de Santa María la Mayor de Antequera". El Sol de Antequera. "Plazuela", 29 de mayo 1982. 
Escultores y pintores del círculo antequerano del XVI. Aportaciones...

Como se habrá podido apreciar en este documento, que hemos transcrito en su parte fundamental, nos aparece Francisco Gutiérrez de Lepe, apodo con el que era conocido el alarife Francisco Gutiérrez Garrido, dato bastante importante como veremos más adelante.

En este año de 1580, Juan Vázquez de Vega tenía su domicilio en calle Fresca, entre las casas de Alonso de Balza y la de los hijos menores de Juan de Carvajal, a quienes se la arrendó por precio de veinte ducados y por un período de un año. En el contrato de este arrendamiento se recoge que el artista además de la cantidad consignada debería de aportar como parte del precio del arrendamiento su trabajo en la limpieza y restauración de unos frescos que se encontraban en mal estado en la mentada casa ${ }^{8}$.

El 16 de abril de 1587, Juan Vázquez, concierta con la beata María de Santo Domingo ... de hazer una ymagen del glorioso Santo domingo de bulto e madera de siete quartas destatura de alto en la una mano un libro y En la otra una cruz el quento y ravo della metido En la boca de una sorrilla que a de estar A los pies de la dha Ymagen La qual A de ser gueca por las espaldas y En lo que toca A la pintura se ha de dar el avito negro y en a la rredonda por la orilla una orla de oro y negro pintada de tres dedos de ancho y el manto estrellado de oro y en la frente Una estrella grande de oro y en el lado yzquierdo siete estrellas doradas xuntas y a la capilla sea de dar la misma ora Ladura con su tunica y escapularío blanco con una orilla de una dedo de ancho de oro lizo y de la dha cruz y orlas doradas y con estrellas Las tablas y gravado y los çapatos negros Y la peana de la dha ymagen a de ser verde sobre que a de tener los pies.... ${ }^{9}$

El 18 del mismo mes y año, nuestro artífice firma un pliego de condiciones ${ }^{10}$, con el alarife Francisco Gutiérrez Garrido y el escultor Juan de Montes, contratando la policromía y las pinturas de un retablo en cuya hornacina central iría la imagen de bulto de una Virgen, indicando que debe ser igual que el retablo de Gonzalo de León. No se especifica más, y en la actualidad en nuestra ciudad no se conserva ningún retablo que se amolde a la descripción que en el dicho pliego se efectúa. En cuanto a la referencia que se hace en el documento al retablo de Gonzalo de León, hemos de señalar que el referido retablo se ubicaba en la iglesia del convento de San Agustín, y fue contratada su hechura, en un principio, entre el dicho Gonzalo de León escribano del cabildo y público de esta ciudad y el alarife Francisco Gutiérrez el 14 de abril de $1584^{11}$, que no llegó a ejecutarlo, ya que el 5 de mayo de 1586 , el referido escribano, realiza un nuevo contrato para la hechura del retablo de su capilla, esta vez con Juan Vázquez de Vega ${ }^{12}$, que sin duda debió de hacerlo. De

${ }^{8}$ A.H.M.A. - F.P.N. Escribano: Juan Pérez Berrio. Legajo 943, fols. 272r - 272v.

${ }^{9}$ A.H.M.A. - F.P.N. Escribano: Juan Fernández Aguilar. Legajo 311, fols. 206r - 207v. Esta imagen, que no la hemos podido localizar en Antequera, es muy posible que ya no exista.

${ }^{10}$ A.H.M.A. - F.P.N. Escribano: Benito Sánchez Herrero. Legajo 1.464, fols. 502r - 503r.

11 A.H.M.A. - F.P.N. Escribano: Cristóbal Méndez. Legajo 1.194, fols. 466v - 468r 


\section{José Escalante Jiménez}

este retablo la única pieza que se conserva es la imagen de bulto que iba en el centro, un San Roque. Se trata de una escultura de aproximadamente 1,30 m. de altura delicadamente estofada y con los atributos del santo.

Además de estas obras, tenemos que el 27 de agosto de 1588, Juan Vázquez contrata con Juan de Berlanga la hechura de una imagen de Nuestra Señora del Rosario para localidad malagueñ் de Teba por precio de 36 ducados $^{13}$. El trece de febrero de 1590, el Cabildo de la ciudad de Antequera le encarga la policromía de una talla de Santa Tecla ${ }^{14}$. En este mismo año de 1590, la cofradía del Apóstol San Pedro de la ciudad de Lucena ${ }^{15}$ le tiene encomendado a Juan Vázquez de Vega y a Antonio Mohedano de la Gutierra la policromía de una imagen de San Pedro, que fue tallada por Pablo de Rojas; en el documento se recoge que ambos artistas son vecinos de Antequera y naturales de Lucena. El 15 de octubre de 1592, Juan Vázquez realiza el dorado y pintura de un sagrario para el convento de Nuestra Señora de la Encarnación de Antequera, y además:

... que dos tableros questan a los lados tengo de pintar En ellos dos Santos de la orden de nrs a del carmen que an de ser santo alberto que a destar a la mano derecha y santo angelo a la siniestra... ${ }^{16}$

Haremos referencia ahora a otra importante obra desaparecida: el retablo mayor de la iglesia franciscana de San Zoilo. El 9 de febrero de 1594 ... Antonio mohedano y Joan bazquez Estan convenidos y consertados con Alonso rrodríguez pinazo síndico del convento de señor san francisco desta ciudad de dorar y pintar Un rretablo questa En El Altar mayor del dho convento de señor San Francisco de la forma y manera que se contiene En un memorial que va inserto con Esta Escritura. ..

El referido pliego de condiciones es el que a continuación transcribimos en su integridad dado su interés:

Condícíones con que sea de hazer El Retablo de Sant Franc ${ }^{\circ}$ Para satisfacion del Padre guardian y convento

lo primero del Reparto de las maderas.

Primeramente que todas las maderas antes de a Parejillas sean de Reparar y fortalecer contra todos los vicios que con El tiempo les

\footnotetext{
12 A.H.M.A. - F.P.N. Escribano: Juan Pérez Berrio. Legajo 915, fols. 146v - 148v

13 A.H.M.A. -F.P.N. Escribano: Benito Sánchez Herrero. Legajo 1.476, fols. 1.516r 1516v.

14 A.H.M.A. - F.P.N. Escribano: Gonzalo de León. Legajo 35, fol. 92r.

15 GONZÁLEZ ZUBIETA, R.: Vida y obra del artista andaluz Antonio Mohedano de la Gutierra (1563?

- 1626). Córdoba, 1981.

16 A.H.M.A. - F.P.N. Escribano: Pedro Gutiérrez Alvarez. Legajo 2.740, fols. 965r - 966v.
} 
Escultores y pintores del círculo antequerano del XVI. Aportaciones...

suelen venir los tableros con cañamo pardos hazer y la demas arquitectura con lienços ques negocio que importa mucho como fundamento de toda la obra, ansi de dorado como de Pintura.

de los aparejos

Es condicion que los aparejos ande ser firmes y delgados de suerte que no se ofusque ni pierda filete ni membrezillo de toda la arquitectura.

del dorado

que toda la arquitectura sea de oro puro salvo Las figuras de medio relieve que estas an de ser estofadas de colores y encarnadas de pulimento y todo lo demas como digo de oro puro y para hermosura de la obra se hagan algunas cosas de talla molduras de oro crespo que se despeguen y diferencien de las cosas llanas que an de ser bruñidas.

de la pintura

Es condicion que todos los tableros lisos an de ser de Pintura buena ansi historia como figura sola como nos fuere señalado y que a de ser hecha de manera que desde lexos ques dedo sea de mirars alga confuerça qualquiera cosa de suerte que nada se pierda de vista sino que todo segoze como sí estuviese cerca y con buenos colores firmes y duraderos.

de las obligaciones

que para efecto deste obra señalado El tiempo En que se a dedar hecha nos obligamos al tiempo nombrado y efecto della de darla hecha con las condiciones dhas dando fiança firmes y seguras y el convento por su parte haga lo mesmo dando persona llana y segura con bienes firmes.

de desarmar y armar El Retablo

Es condicion quel convento dearme y arme El Retablo a su costa y que nosotros nos hallemos al desarmar Para señalallo por numeros y ni mas ni menos nos ha llemos al armallo Para poner cada cosa En su lugar y governallo

En lo restante de las Pagas En la obligacion quedara rresuelto de la manera que an de ser advírtiendo que nos obligamos a hazerlo En el presío En que se Resolvio delante de Alonso de carrion mercader y del Regídor alcoba y el Padre garcia morales El Retablo fue de la 
José Escalante Jiménez

manera que aora esta y aquello que allí esta hecho se conserto de dorar y Pintar.

Son seiscientos y quince ducados

ansi mysmo es condicion que las figuras quean de y En las caxas de enmedio que son san zoylo y un cristo crucificado y san joan y ntra señora las an de dorar ansímismo y acaballas con toda perfecion y el convento las a de dar fechas de madera dentro deste mes a contar desde el día de la fecha

Las ymagenes de talla pintallas (tachado) a testa estas condiciones de las ymagenes de tallas pintallas ${ }^{17}$.

Este retablo fue sustituido por la comunidad franciscana, en el año 1787, por el actual de estilo de transición del rococó al neoclásico y obra del retablista antequerano Antonio Palomo.

El treinta y uno de marzo de 1594 Juan Vázquez de Vega policroma una imagen de Nuestra Señora para el convento de la Encarnación de esta ciudad ${ }^{18}$. En 1596, el 22 de enero, contrata con Pedro Bemal y Teodoro Maldonado, la policromía de una talla de un Cristo Resucitado para los hermanos de la cofradía de la Soledad de la localidad de Campillos, por precio de 300 reales $^{19}$. Esta talla fue realizada por el escultor Andrés de Iriarte como veremos más adelante.

El último dato que tenemos hasta ahora de nuestro artífice es de 1597, y es un importante documento que nos acredita una vez más la faceta escultórica de este artista:

Sepan quantos esta carta vieren como yo Juan de Pastrana vezino que soy en esta mui noble ciudad de antequera híxo lixítimo e natural de tomas moreno de cabrilla vezino quefue della... declaro que entro por aprendiz con Juan Vazquez natural de la villa de luzena carpintero de blanco entallador y ensamblador rresidente en esta dha ciudad ques presente por tiempo y espacio de veinte e dos messes que an de començar a correr desde mañana primero de enero... ${ }^{20}$

Además de este artista sabemos, que nació en Lucena el 13 de octubre de 1549, fue bautizado en la iglesia parroquial de San Mateo. Contrajo matrimonio en

\footnotetext{
17 A.H.M.A. - F.P.N. Escribano: Alonso Aguilera. Legajo 913, fols. 373r - 375v.

18 A.H.M.A. - F.P.N. Escribano: Pedro Gutiérrez Alvarez. Legajo 2.793, fols. 500r - 501v.

19 A.H.M.A. -F.P.N. Escribano: Francisco Rodríguez León. Legajo 65, fols. 60v - 62r.

20 A.H.M.A. - F.P.N. Escribano: Rodrigo Alonso de Mesa. Legajo 1.287, fols. 5r - 6v.
} 
Escultores y pintores del círculo antequerano del XVI. Aportaciones...

la ciudad de Antequera el 12 de enero de 1592 en la parroquia de San Salvador con María Alvarez Cermeño, de su matrimonio nacieron tres hijos Juan en 1592, Jeronimo en 1593 y María en 1595. Por ultimo nos consta que en febrero de 1599 había ya fallecido, al otorgar su esposa María Alvarez Cermeño una escritura de obligación con un tal Juan de la Cruz Ordoñez, en la que manifiesta ser viuda de Juan Vázquez de Vega.

\section{DIEGO DE VEGA}

De todos los escultores documentados hasta ahora durante el ultimo cuarto del siglo XVI en Antequera, destaca sin lugar a dudas la figura de Diego de Vega, de quien tenemos constancia que fue hijo de un tal García Ruiz y de María de Vega. Contrajo dos veces matrimonio en nuestra ciudad, el primero fue el seis de noviembre de 1575 con Luisa Rodríguez, de la que tuvo tres hijos: María, nacida el 17 de noviembre de 1575; Luisa el 4 de septiembre de 1580 y Juan el 10 de diciembre de 1581. En 1583, el 29 de agosto, contrae nuevo matrimonio, esta vez con una tal Isabel de Reina ${ }^{21}$.

En cuanto a sus obras caben destacar las siguientes:

En 1577, el dieciocho de diciembre, Juan Rodríguez Palomero, vecino de Archidona, encarga a Diego de Vega la hechura de un crucificado de cinco cuartas de alto por precio de diez ducados. El 17 de enero de 1578, contrata con Juan González vecino de Antequera un retablo de tres cuerpos para la iglesia del Colegio de Santa María de Jesús. Las medidas de este retablo eran de 2,50 metros de alto por 1,88 metros de ancho: En el banco llevaba tres tallas en medio relieve, representando a Santa Lucía, Santa Catalina y una Magdalena. En el cuerpo central cuatro columnas estriadas, encuadrando las imágenes también de medio relieve de San Francisco penitente, San Antonio y Santa Isabel de Hungría. El ático estaba formado por dos columnas que cargaban un medio punto adornado con siete serafines, en el centro del cual y debajo del frontis, se ubicaba un Crucifijo con un San Juan y una Dolorosa a los lados, y en los extremos las imágenes de San Lorenzo y San Gregorio. El precio pactado fue de cuarenta y ocho ducados. Este retablo no se conserva en la actualidad 22 .

El 17 de marzo de 1578, Pedro Fernández de Lemar, Marcos Jiménez Lozano y Juan Fernández de Astorga, vecinos de Archidona, convienen con el entallador Diego de Vega, la hechura de un Crucificado, una Dolorosa, un sepulcro, tres pares

${ }^{21}$ ESCALANTE JIMÉNEZ, J.: "Diego de Vega: una aproximación a su vida y obra (1575-1583)". El Sol de Antequera. Especial Semana Santa, 1992.

22 A.H.M.A. - F.P.N. Escribano: Alonso Gómez Adalid. Legajo 164, fols. 22r - 24v.

23 A.H.M.A. - F.P.N. Escribano: Alonso Gómez Adalid. Legajo 164, fols. 300r - 300v. 


\section{José Escalante Jiménez}

de parihuelas y una cruz con su calvario, por precio de treinta y dos ducados. Se trata de las imágenes que hoy procesiona la cofradía de Nuestra Señora de la Soledad y Santo Entierro de la citada localidad de Archidona, y que durante tanto tiempo han estado atribuidas al imaginero Pablo de Rojas ${ }^{23}$.

El 30 de marzo de 1581, los hermanos de la cofradía del Nombre de Jesús de Antequera, Juan Mir del Aguila y Lucas Méndez, encargan a nuestro entallador una imagen de Cristo Nazareno, llevando la cruz a cuestas. En el contrato se especifica que la talla se debe reducir a cabeza, pies y manos y que el resto del cuerpo tiene que ser de telas encoladas. No cabe la más mínima duda de que se trata del Nazareno que actualmente se procesiona en la noche del Viernes Santo por la Archicofradía del Dulce Nombre de Jesús y Nuestra Señora de la Paz, la popular cofradía de "Abajo" de Antequera ${ }^{24}$.

El 26 de enero de 1582, el mayordomo de la cofradía del Santo Crucifijo, del convento de San Agustín de Antequera, firma un finiquito con Diego de Vega por la hechura de un Cristo Crucificado, que la referida hermandad le había encargado, y que estaba ya en su poder. Esta imagen es la que en la actualidad procesiona la mencionada cofradía del Dulce Nombre de Jesús, bajo la advocación del Santísimo Cristo de la Buena Muerte y de la $\mathrm{Paz}^{25}$.

... maria magaña bíuda muger quefue de luis verdugo vezina de la villa de teva le mando hazer Una ymaxen de nuestra señora con un tevernaculo y dos ymagenes pintadas en las puertas por prescío de treynta y ocho ducados... ${ }^{26}$.

En tanto, el 2 de abril de 1582 Diego de Vega se,

... Obligo con marcos hernandez exptoval diaz vezinos de la villa de La rroda de le dar fechas y acabadas dos ymagenes La una de señor san sevastian e la otra de señor santíago apostol bienfechas e acabadas La ymagen de san sebastían de cinco quartas e una ochava con su peana Ela de Santiago de seys quartas con su peana apostolado vestido e dorado con todo lo que le conviene e ambas ymagenes Acabadas e puestas en perfecion de todo punto hechas y acabadas I-a de San sevastian El dia de Santiuan dejunio primero venydero deste presente año E la de santíago en ocho dias antes del dia de santiago primero deste año Porque por las hazer los suso dhos mean de dar por la de san sevastían diez y seis ducados E por la de santiago veynte y dos ducados..."27

\footnotetext{
24 A.H.M.A. - F.P.N. Escribano: Beiiito Sánchez Herrero. Legajo 1.471, fols. 942r- 943v.

25 A.H.M.A. - F.P.N. Escribano: Cristóbal Méndez. Legajo 384, fols. 138r - 138v.

26 A.H.M.A. - F.P.N. Escribano: Benito Sánchez Herrero. Legajo 1.433, fóls. 88r - 88v.

27 A.H.M.A. - F.P.N. Escribano: Benito Sánchez Herreo. Legajo 1.433, fols. 554r - 555v.
} 
Escultores y pintores del círculo antequerano del XVI. Aportaciones...

Con el racionero Juan de Aguilar contrata un retablo en 1577, para su capilla en la Real Colegiata de Santa María la Mayor. Se trata de una ensambladura de 4x $7 \times 2$ '50 metros, con nueve tableros de talla de medio relieve distribuidos en tres calles representando de abajo arriba y de izquierda a derecha, en el primer cuerpo a San Bartolomé; Crucificado con San Juan, la Virgen y la Magdalena al pie de la Cruz; San Miguel. En la calle central, Santa Catalina, una Purificación, Santa Lucía. Y en el cuerpo superior, un Jesús en el momento de ser crucificado; un Nazareno; un Cristo amarrado a la columna con unos sayones azotándolo. Rematado todo el conjunto con un frontispicio con una imagen de un Cristo Resucitado.

El precio pactado para la obra fue de ciento veinticuatro ducados y el plazo para su realización de año y medio ${ }^{28}$.

\section{ANDRÉS DE IRIARTE}

Otro escultor que trabajó en Antequera en esta época de la que estamos hablando fue Andrés de Iriarte. De él sabemos que el 10 de octubre de 1595 se obliga con Pedro Bernal y Teodoro Maldonado vecinos de Campillos y hermanos de la cofradía de Nuestra Señora de la Soledad de la referida localidad:

... de hazer una hechura de cristo rresucitado de madera maciça e seca de cerezo entallado con su peana e diadema con tres potencias de laltura e tamaño acabado en perfecion como el Apto rre(ucitado del convento del carmen desta dha ciudad Abista e contento d ejoan Bazquez e antonio mohedano vezinos desta ciudad. ${ }^{29}$.

Esta talla, como hemos visto anteriormente, fue policromada por Juan Vázquez de Vega.

En 1597, Pedro García, mayordomo de la cofradía de la Oración del Huerto de la villa de Cañete la Real, contrata por precio de veinte ducados con Andrés de Irlarte: ... una figura de xto de cuerpo que este orando incado de rrodillas la qual a de tener dos varas en largo y cinco quartas íncado de rrodillas y tres quartas lebantado en su peana y un angel de media vara poco mas o menos con un caliz en la mano izquierda y en la derecha una cruz con un arbol y un belo de donde a de salir la figura de dho angel ${ }^{30}$.

\footnotetext{
28 A.H.M.A.-F.P.N. Escribano Alonso de Aguilera, legajo 944, folios 413r a 415v. Ver anexo documento n.- 5 .

${ }_{29}$ A.H.M.A. - F.P.N. Escribano: Francisco Rodríguez León. Legajo 2.005, fols. 884r -885v.

30 A.H.M.A. - F.P.N. Escribano: Diego Vilchez. Legajo 648, fols. 40r - 42v.
} 
El 17 de noviembre de 1598, este maestro de escultura, pacta con Juan Ramírez Cordonero, y Alonso Carlos, vecinos de Antequera, la hechura de un San Blas para la iglesia parroquial de San Sebastián ${ }^{31}$. Esta imagen tampoco se conserva, ya que la actual es de Andrés de Carvajal.

En el año 1600, según referencia verbal del P. Andrés Llordén al historiador Jesús Romero Benitez, Andrés de Iriarte hizo una talla de la Virgen de Gracia, similar a la de los Trinitarios de Granada, para la ermita de San Bartolomé. Esta se conserva actualmente en la capilla del Sagrario de la iglesia de los Remedios de Antequera y se la viene denominando como Virgen del Rosario.

En 1601 compra una casa al pintor José Hernández, en la calle de la Puerta Chica del convento de San Francisco, es decirla actual calle Trasierras ${ }^{32}$. Contrajo matrimonio en 1602 con María Muñoz del Castillo, en la iglesia parroquial de San Pedro $^{33}$, esta era hija de Francisco Sánchez del Castillo, y a su vez hermana del también importante escultor Juan Bautista del Castillo. María Muñoz, otorga carta de dote a favor de su esposo, el 19 de agosto del mismo año, aportando bienes por valor de 124.561 maravedies $^{34}$.

Volviendo con su obra, en 1592, Juan de León Belmonte le encarga la hechura de un Cristo Resucitado de dos varas de altura en madera de pino, por el cual pagará 244 reales $^{35}$. Esta imagen podría ser perfectamente la que se conserva en la iglesia de Nuestra Señora del Carmen de Antequera.

En 1594, Juan López Melero encarga a Andrés de Iriarte por precio de 17 ducados un Cristo crucificado muerto de siete cuartas de tamaño. Esta escultura no ha podido ser localizada ${ }^{36}$. En 1601, Iriarte contrata con Pedro Maldonado ... vezino de la villa de almogia que esta presente Una ymaxen de san rroque de grandor $e$ proporcion que El questa En la capilla de Gonçalo de leon ques en el convento de señor san agustin y a de yr con angel todo dorado.. ${ }^{37}$

Por último indicar que Andrés de Iriarte fallece en 1604, otorgando testamento el 27 de octubre de dicho año, aportándonos en el referido documento un importante inventario de obras, que transcrito en su parte fundamental nos dice:

... Yten mando que quando la voluntad de Dios nuestro señor fuere servída de me llebar desta presente vida mí cuerpo sea sepultado En la yglesia de señor san francisco desta ciudad En la capílla de la sangre de donde soy hermano...

\footnotetext{
31 A.H.M.A. - F.P.N. Escribano: Martín Vergara Alvarado. Legajo 957, fols. 816v - 817r.

32 A.H.M.A.-F.P.N. Escribano Agustín Méndez, legajo 29, folio 82v.

33 A.H.M.A.-F.P. Archivo de la Parroquia de San Pedro. Matrimonios. Libro II, folio 318.

34 A.H.M.A.-F.P.N. Escribano Juan de Villalba, legajo 1.723, folios $343 \mathrm{r}$ a $346 \mathrm{v}$.

35 A.H.M.A.-F.P.N. Escribano Benito Sánchez Herrera, legajo 1.333, folios 721 r a 721 r. anexo documento n." 6.

${ }^{36}$ A.H.M.A.-F.P.N. Escribano Diego de Carvajal, legajo 1.908, folios 351r a 352v. Ver anexo documento n." 7.

37 A.H.M.A.-F.P. N. Escribano Juan de Villalba, legajo 1.723 , folios $281 \mathrm{v}$ a $282 \mathrm{v}$.
} 
Escultores y pintores del círculo antequerano del XVI. Aportaciones...

... Yten declaro que el Jurado anton garcia portillo me mando hazer una hechura de señor San lorenzo e para en quenta de lo que me avía de dar de mi travajo tengo rrecividos seis ducados niando que se le rrecivan en quenta acavandose La dha hechura...

... Yten mando y declaro que ami me mando hazer frai graviel de la cruz de la orden de nuestra señora del carmen una hechura de señor santangelo e para enquenta dello mea dado quatro ducados mando se le recivan en quenta...

... declaro que me debe la cofradía de la umildad questa En nuestra señora de la vilorta e firancisco de aragon en su nombre ciento e noventa e un reales de ciertas hechuras que hize para la dha cofradía mando que se cobren del dho franc ${ }^{\circ}$ de aragon declaro que me debe franc $^{\circ}$ de Moreno quatro ducados y medio de ciertas hechuras que híze mando que se cobren del declaro que me deve rníguel de la torre vezino desta ciudad veinte e un rreales mando que se cobren del Yten declaro que me debe alonsso gil el moço vezino desta ciudad diez y seis rreales de una hecluira de un xpto que le hize mando que se cobren del declaro que me debe francísco de velman vezino de La villa de archidona diez rreales mando que se cobren del declaro que me debe pedro covo vezino de la villa de alora diez rreales de una hechura de una cruz mando que se cobren del o buelba la dha hechura declaro que alonso rrodriguez pinazo vezino desta ciudad me a dado diez y seis ducados a quenta de ciertas hechuras que me mando hazer e por no averlas acavado se entregue una hechura de un xpto la qual dha hechura merecida de my travajo veinte y quatro ducados de forma que de a dha hechura que le tengo entregada me deve ocho ducados declaro que me deben las monjas de santa clara cien rreales de la hechura de una ymaxen de santa clara mando que se cobren declaro que pedro ponse vezíno de la villa de archídona me mando hazer ciertas hechuras muchosos días A e para quenta medio doze ducados e me quedo A deber para quando le entregara las dhas hechuras diez y seis ducados mando que si las dhas hechuras se le entregaron mando que se cobren del ...".

En el mismo testamento, manifiesta no tener hijos y nombra por su única heredera a su esposa ${ }^{38}$.

38 A.H.M.A.-F.P.N. Escribano Juan de Villalba, legajo 1.718 , folios $181 \mathrm{r}$ a $184 \mathrm{v}$. 


\section{José Escalante Jiménez}

\section{BALTASAR LÓPEZ}

De Baltasar López sabemos que en 1581 realiza una imagen de Nuestra Señora del Rosario para la cofradía de la Caridad de Antequera. ${ }^{39}$

El seis de diciembre de 1583, Baltasar López se obligó con:

... la cofradia y hermanos de nuestra señora del rrosario de la villa de pedrera y el señor licenciado xptoval de castro de la orden de santíago cura de la yglesia de la dha villa de pedrera y a quien de ellos lo oviere de aver una ymaxen de bulto de nuestra señora de materia de pasta de lienços de estatura de siete quartas de alto poco mas o menos con su corona y manto dorados de la forma que se rrequiere Para estar acabada en perfecion... ${ }^{40}$

\section{LUIS DE HAYA}

Para el vecino de la villa de Álora Juan Vázquez Bajamón, el escultor Luis de Haya talla, el 31 de octubre de 1592, un San Francisco de cinco cuartas de alto por precio de 14 ducados para el monasterio de San Francisco de Antequera. ${ }^{41}$ Esta escultura será policromada en 1593 por el pintor José Hernández ${ }^{42}$. Otra obra que hemos documentado de este escultor es una imagen de un San Juan Evangelista de siete cuartas que le encarga un vecino de Málaga, en 1595, llamado Diego Bastardo. ${ }^{43}$

\section{LUIS FERNÁNDEZ}

De este pintor tan sólo tenemos que en 1580 realiza un retablo para el convento de la compañía de Jesús por encargo de Benito Sánchez de las Sercas y Nicolás Ruiz, por precio de 66 ducados. El retablo fue realizado por completo en tableros pintados, los temas de los seis centrales divididos en tres calles eran en los dos centrales un Crucificado con San Juan y la Virgen a los lados; y el parto de Santa Ana. Y en las otras calles, una Concepción; San Juan Bautista; San Miguel; y Santa Catalina. ${ }^{44}$

39 BARRERO BAQUERIZO, F.: Historia de Antequera, 1741, ms.

${ }^{40}$ A.H.M.A. - F.P.N. Escribano: Diego de Carvajal. Legajo 1.766, fols. 470r - 471v.

41 A.H.M.A. - F.P.N. Escribano: Diego de Vilchez. Legajo 19, fols. 696r - 697v.

42 A.H.M.A. - F.P.N. Escribano: Juan Villalba. Legajo 1.894, fols. 120r - 12 Iv.

${ }^{43}$ A.H.M.A.-F.P.N. Escribano Bartolorné de Porras, legajo 1. 127, folios 81 lv a 812 r. Ver anexo documento n." 8.

44 A.H.M.A.-F.P.N. Escribano Alonso de Aguilera, legajo 922, folios 739v a 742r. Ver anexo documento n. 9 . 
Escultores y pintores del círculo antequerano del XVI. Aportaciones...

\section{JUAN DE MONTES}

Escultor de origen flamenco, sabemos que vivió en la calle del Río y que debió de tener algún vínculo de amistad con el maestro alarife y estuquista Francisco Gutiérrez Garrido, ya que el mismo actúa como avalista tanto en el arriendo de la casa, ${ }^{45}$ como en el contrato de su única obra documentada, que por desgracia no se conserva. Se trata de un retablo para la capilla del escribano público Alonso Nieto en el convento de San Agustín.

El trabajo lo encarga la viuda del referido escribano, doña Leonor de la Torre en 1586 por precio de 276 ducados. Este retablo tenía que tener una altura desde el frontis hasta el asiento del banco de 3'62 metros y un ancho de 2'78 metros. Mezclaba los motivos realizados a pincel con los temas representados en medio relieve, la figura central era una imagen de bulto de Nuestra Señora de las Necesidades, ... ymagen de nuestra señora con un niño En los braços y a destar en pie de bulto rredondo con un vestido y rropage a lo greciano... ${ }^{46}$ Este retablo fue dorado y estofado en 1587 por Juan Vázquez de Vega. ${ }^{47}$

\section{ALONSO QUINTERO.}

Pintor al que se le encarga en 1595 la decoración de la capilla de la cofradía de San José en el Real Monasterio de San Zoilo. Esta capilla se ubicaba en el compás del convento y entre otras cosas los hermanos de la cofradía le encargan a Alonso Quintero una sarga en la que tenía que ir representado un Niño Jesús y un San José. En el contrato actúa como avalista el también pintor José Hernández. ${ }^{48}$

\section{JOSE HERNÁNDEZ}

Pintor y escultor, que desarrolla su actividad entre el último cuarto del siglo XVI y principios del XVII. Hijo de Pedro Hernández y de doña Francisca de Toro, contrae matrimonio en la iglesia parroquial de San Isidro, el 24 de agosto de 1586. Fue hermano de la cofradía de la Sangre y Santa Vera Cruz. En cuanto a su obra, hasta ahora solamente se le tenía documentada la policromía de la talla de un San Francisco ejecutada por el escultor Luis de Haya, a lo que hay que sumarle una

\footnotetext{
45 A.H.M.A.-F.P.N. Escribano Benito Sáncliez Herrera, legajo 1.422, folio 1.272v.

46 A.H.M.A.-F.P.N. Escribano Diego de Carvajal, legajo 1.868, folios 274r a 277v. Ver anexo documento n. 10.

47 A.H.M.A.-F.P.N. Escribano Benito Sánchez Herrera, legajo 1.464, folios 5()2r a 503r. Ver anexo documento $\mathrm{n}^{\circ} 11$.

48 A.H.M.A.-F.P.N. Escribano Alonso de Aguilera, legajo 926, folios 201r a 202v. Ver anexo documento n.' 12.
} 


\section{José Escalante Jiménez}

imagen de bulto de una San Roque que le encarga Juan Ruiz Burgueño para la cofradía de la Soledad. El contrato en su parte fundamental dice así:

... una ymaxen de bulto de senor san rroque de estatura de vara y media de pasta con peana labrado el rropaxe al temple galanteado con unos orofreses e guarnicion sembrados nnos purpurítos de oro en las partes donde mas convengan rrostro y manos encarnados de pulimento Al lado con un angel y un perro por ynsignia de la altura E proporcion que convengan el cual tengo de dar Acabado a fin deste presente mes de mayo en toda proporcion e presencia A vista de Hernando Luque y a contento del dho juan rruyz burgueño e de los alcaldes que son de la dha cofradia... ${ }^{49}$

En 1591 José Hernández, junto con el también escultor Andrés de Iriarte, ...se obligavan y obligaron de hazer y entregar a blas navarro questa presente vezino de la ciudad de Estepa... una figura de Sant blas obispo de cinco quartas de alto sin la peana todo dorado y estofado lo que conviene fho y acavado e a contento de Personas que lo entiendan... ${ }^{50}$ por el que cobran la suma de dieciocho ducados y medio, haciendo la entrega el día de Navidad.

Y por último en 1592, doña Isabel de Narváez, da carta de pago a nuestro escultor y pintor, por la hechura de un Cristo. El instrumento público, se redactó en la siguiente forma:

En la muy, noble ciudad de antequera en nuebe dias del mes de mayo de mill e quinientos e noventa e dos años en presencia de mi el escrivano plublico y testigos de yuso escriptos Jusepe hernandez vecino desta ciudad dorador de Ymaxenes al cual yo el dho escrivano doy fee que conozco otorgo aver rrecibido E que rrecibio de dona Ysabel de Narbaez viuda muger que fue de fco. muñoz rredroxo quesea en gloria dos ducados en mi presencia e de los testigos de yuso Escriptos de que doy fee E con los dhos dos ducados el susodho declaro estar pagado de veinte $e$ un ducados que la dha dona Ysabel esta obligada a el pagar de la mitad de la hechura de un cristo que la hecho para una capilla de la susodha y de don pedro de padilla El qual le a de pagar la otra mitad.... otro si el dho jusepe Hernandez díxo que porque en el paño que lleba la hechura del dho cripsto a hecho ciertas demasias que la mitad dellas acabado de hacer la dha dona Ysabel Lea de pagar La dha mitad de demasia... ${ }^{51}$

\footnotetext{
${ }^{49}$ A.H.M.A.-F.P.N. Escribano Francisco Giniérrez Alvarez, legajo 2.778, folios 377r a 379v.

${ }^{50}$ A.H.M.A.-F.P.N. Escribano Benito Sáncliez Herrera, legajo 1.478, folios 2.732r a 2.732 .

51 A.H.M.A.-F.P.N. Escribano Gonzalo de León, legajo 19, folios 285r a $285 \mathrm{v}$.
} 
Escultores y pintores del círculo antequerano del XVI. Aportaciones...

Isabel de Narváez fue copatrona de la capilla Mayor de la iglesia parroquial de San Salvador, en cuyo altar estaba ubicada una imagen de un Cristo crucificado, que en la actualidad se encuentra depositado en la iglesia del antiguo convento del Carmen, y que es denominado como Cristo de la Paz. Se trata de una escultura de gran belleza plástica que representa a Cristo crucificado y muerto, con la cabeza inclinada sobre su pecho. El tratamiento anatómico es correcto, las piernas aparecen ligeramente flexionadas y los pies atravesados por un solo clavo.

\section{CRISTÓBAL DE MESA}

También pintor, al cual le encomienda el Regidor don Fernando Chacón de Narváez en 1596 el pintar ... en un paramento de tarasea diablillos e mascaras para las fiestas del corpus.. ${ }^{52}$.

\section{ALONSO MARTÍN ALAMILLA}

De este ensamblador sabemos que estuvo activo en nuestra ciudad entre 1577 fecha en la que otorga carta de dote a favor de su esposa doña Magdalena de la Paz ${ }^{53}$ y 1604 fecha en la que dispone su testamento y últimas voluntades ${ }^{54}$. De su obra adelantamos que realizó el retablo mayor de la capilla de la Archicofradía de la Sangre de Antequera y toda la obra de carpintería del convento de Santa Clara, igualmente de Antequera. Nada se conserva de su obra hasta ahora documentada.

Para finalizar esta breve nómina de artistas del círculo antequerano del siglo XVI nos hemos reservado la figura que, a nuestro entender, tiene una mayor relevancia y peso especifico en el desarrollo de las artes plásticas dentro de este conjunto. Se trata de Antonio Mohedano de la Gutierra.

\section{ANTONIO MOHEDANO DE LA GUTIERRA}

Pintor dorador, arquitecto y poeta. De Mohedano nos dice el historiador Francisco Barrero Baquerizo:

...en la píntura se adelantaron sus pinceles a el famoso Apeles; fue contemporaneo del Rasionero Cano, que siempre benero a nuestro

\footnotetext{
52 A.H.M.A.-F.P.N. Escribano Miguel Fernández Merodio, legajo 325, folios 387r a 387v.

53 A.H.M.A. - F.P.N. Escribano: Gonzalo Fernández dela Torre. Legajo 1.704, fols. 871r

$-872 v$.

${ }^{54}$ A.H.M.A. - F.P.N. Escribano: Gonzalo Fernández dela Torre. Legajo 1.704, fols. 871r- 872v.
} 
José Escalante Jiménez

patrisio, y alavo sus obras. Vino Esprofeso a rreservarse en su pintura, en tiempo que delineava las dos laminas fronteras que oy estan en la Capilla maior del monasterio de San francisco de la observansía y fue admirado...

Efectivamente este artista, contó en su época con la admiración y justa valoración de su obra. Pero mala suerte le cupo en la posteridad al no interesar a la crítica ni a los investigadores. El tiempo tampoco ha sido justo con el maestro Mohedano, habiendo desaparecido gran parte de su obra, de su labor en la ejecución de frescos nada queda y de su pintura en lienzo muy poca está documentada.

Poco se sabe, igualmente, de su niñez y juventud, tan sólo el investigador de temas lucentinos Rafael González Zubieta, con su Vida y obra del artista andaluz Antonio Mohedano de la Gutierra, aborda de una forma profunda las raíces y producción de este importante personaje. Con este presente trabajo, queremos aportar una serie de documentación que confiamos sirvan para realzar en su justa medida la meritoria labor de Antonio Mohedano.

Sobre la fecha de asentamiento en Antequera de Mohedano existen diversas opiniones, hoy podemos adelantar que al menos en 1589, el pintor vivía ya en nuestra ciudad. En esta fecha arrienda por un año y precio de nueve ducados una casa en la villa de Lucena a don Juan de Aguilar Sotomayor en la calle del Alcalde, linde con casas del arrendador ... para que en ellas biba maria de la Gutierra mi hermana por la qual salgo pagador... ${ }^{55}$

El 6 de mayo de 1592 Mohedano contrata con Francisco Ordóñez Retamal la decoración de la capilla de la cofradía de San Diego del Monasterio de San Zoilo, obligándose ... de pintar la dha capilla a lo fresco Los guecos de los quatro arcos hasta el suelo e si se le pidiera que en la frontera donde ha destar el altar haga la misma pintura la ha de hazer de forma que quede adornada con toda perfecion la dha portada.... ${ }^{56}$

En unas recientes obras de restauración llevadas a cabo en el indicado monasterio se han descubierto parte de los arcos colaterales de la nave central, apareciendo restos de pinturas en uno de ellos, concretamente en la denominada actualmente capilla de la Virgen de los Dolores, donde en su día estaba instalado el altar dedicado a San Diego de Alcalá. Estas pinturas, realizadas con la técnica del fresco nos muestran unos dibujos geométricos con un predominio de tonos rojizos y verdosos en el colorido. Sin duda una más profunda actuación sobre la bóveda de la capilla podría aportarnos, aunque posiblemente de manera fragmentada, este trabajo de Antonio Mohedano.

55 A.H.M.A.-F.P.N. Escribano Fernando de Herrera, legajo 1.976 , folios $577 \mathrm{r}$ a $577 \mathrm{v}$.

56 A.H.M.A.-F.P.N. Escribano Alonso de Aguilera, legajo 437, folios 644 a 645v. Ver anexo documento $n^{\circ} 1$. 
Escultores y pintores del círculo antequerano del XVI. Aportaciones...

En 1594, el escribano público del número de Antequera Juan de Merodio, le encarga a Mohedano cinco lienzos al óleo con los temas de la Asunción, la Magdalena, Santa Catalina, la Encarnación y San Francisco. Creemos no se conserva ninguno, o al menos no han sido localizados. ${ }^{57}$

Una obra que ha venido siendo atribuida de forma sistemática a Antonio Mohedano es la Transfiguración de Cristo en el Tabor. Se trata de un lienzo al óleo de grandes dimensiones (2’71 x 2’32 metros, aproximadamente) con figuras de tamaño natural, en el que aparece representado el Salvador junto a Moisés arrodillado con las tablas de la Ley a la derecha y a la izquierda Elías, y los apóstoles San Pedro, Santiago y San Juan en primer término de medio cuerpo. Este cuadro, que se conserva en la iglesia de San Sebastián, fue restaurado en 1985 y venía siendo datado entre 1610 y 1615 .

Esta obra fue contratada, para la Colegiata de Santa María, por don Lope de Suazo de Arébalo el 18 de junio de 1598 por precio de cien ducados, para dar cumplimiento a la voluntad de don Juan de la Puebla que ... mando que de sus bienes se sacasen y tomasen cien ducados para hazer un rretablo en la capilla que tenía $y$ dejo en la yglesia mayor desta ciudad .... 58

También en 1598 Mohedano contrata el dorado, estofado y pintura del retablo mayor de la iglesia de San Mateo de Lucena, trabajo que fue tasado y abonado al artista en 1605. Lo concierta con don Lorenzo de Padilla Nájera y su hermana doña Clara Pacheco. Aportamos en el apéndice documental el referido contrato. ${ }^{59}$

Asimismo en este año de 1598 Antonio Mohedano toma por aprendiz al hijo de un tal Juan Núñez vecino de la villa de Torre Milano (Córdoba), llamado Juan, de 13 años de edad y por tiempo de diez años. ${ }^{60}$

No podemos concluir estas breves referencias de Antonio Mohedano sin aportar su último testamento otorgado once días antes de su fallecimiento ante el escribano Bartolomé González Porras. Transcribimos a continuación este importante documento en su parte fundamental.

Yn Dei nomine Amen SePan quantos esta carta de testamento y ultíma voluntad vieren como yo Antonio mohedano de la gutierra vezino que soy En esta muy noble ciudad de Antequera estando enfermo del cuerpo y sano de la voluntad y en buen juicío memoria y entendimíento...

... Yten mando que quando la voluntad de dios nuestro señor fue de me llevar desta presente bída mi cuerpo sea sepultado en la

57 A.H.M.A.-F.P.N. Escribano Diego de Carvajal, legajo 1.908, folios 324r a 325v. Ver anexo documento n. ${ }^{\circ} 2$.

58 A.H.M.A.-F.P.N. Escribano Juan de Merodio, legajo 708, folios $853 \mathrm{v}$ a $855 \mathrm{r}$. Ver anexo documento n. 3.

59 A.H.M.A.-F.P.N. Escribano Juan de Merodio, legajo 708, folios 992r a 994v. Ver anexo documento n. ${ }^{\circ} 4$.

60 A.H.M.A.-F.P.N. Escribano Juan de Merodio, legajo 708, folios 980r a 980v, 
José Escalante Jiménez

Yglesia de señor San Pedro en la sepoltura que me dieren de la fabríca $Y$ mi cuerpo vaya a la tierra en el abito de señor san franc.

Yten mando me acompañen en mi entierro los clerigos que sirven de ordinario en la dha iglesia de señor san Pedro. Y me lleben a enterrar los hermanos del ospital de senora santa Ana...

... Declaro que sobre las casas de mí morada pago un censo de doscientos ducados de principal al rregidor don rramíro maurizio de san vízente, $Y$ de corridos del le debere el día de pascua de navidad primero venídero fin de este presente año veinte Ducados Yde los demas corridos atrasados tengo carta de pago $Y$ rrecaudos en mi poder.

Declaro que debo a el lícenziado Juan Perez de tudela presvitero vezino desta ciudad quatrocientos rreales que me presto mando que se paguen. Declaro que tengo por mí esclavo cautivo a joan híxo de ana maría mí esclaba que el dícho joan es de presente de edad de tres años $Y$ medio mando que luego que aya cumplido siete Anos sirva A el colexio de la compañia de jesus desta ciudad en el ministerio de la cozina $Y$ de los demas que le mandaren hasta que el dicho Juan tenga edad de veinte años...

Declaro que case con doña maría cabello mi muger Abra veinte y siete años poco mas o menos y de los vienes que a mi poder traxo otorgue escríptura de Dote en su fabor ante Alonso de aguilera escrivano publico que fue desta ciudad y yo lleve a el dho matrimonio por vienes míos quatrocientos ducados poco mas o menos en vienes muebles y aderezos de cassa y desto nose hizo escriptura y no abemos tenido hixos del dho matrimonio.

Yten mando a doña leonor mohedano mi hermana rreligiosa todos los bienes y cossas que al tiempo de mi fallescimiento estubieren dentro en dos Alhazenas y en un escríptorio que tiene tres caxones y la dha Alhazena y escríptorio cada uno tiene un candado pequeño y estan en la (...) donde ordinariamente yo Asisto Y la dha manda hago a la dha mi hermana en la vía e forma que mexora y a lugar de derecho Y mas en su favor haga.. otrosi mando A la dha doña Leonor mohedano mi hermana dos sillas de las que yo tengo las que la suso dha elígiere y quatro rreposteros de los ocho que yo tengo. $Y$ asimismo le mando dos arcas que la dha mí hermana tiene en el quarto de las casas de mi morada donde haze su abitazion. Declaro que los vienes que a mi poder traxo por dote suya la dicha doña maría cabello mi muger son los que le pertenezieron por la partizion de los vienes de sus padres que se hizo entre la suso dha y el lícenciado juan cabello presvitero su hermano y doña francisca cabello su hermana Asimismo muger quefue de andres de begas que la dicha partizion paso ante alonso de 
Escultores y pintores del círculo antequerano del XVI. Aportaciones...

aguilera escrivano publico que fue desta ciudad y aunque por este mi testamento e declarado que le otorgue scriprtura de dote ahora me acuerdo que no se hizo la dha escritura y la hijuela de su aber y entrego de la dha partízion la tengo autorizada en mi poder...

Nombró por albacea al licenciado Juan Pérez de Tudela, presbítero, y ...nombro por mi heredera $A$ mi anima porquanto no tengo heredero forsoso.., fueron testigos Juan Pérez de Tudela, Sebastián López Melgarejo y Bonifacio de Rojas. ${ }^{61}$

Si poco nos aporta sobre su obra pendiente o adeudada este documento, algo mas explícito es el codicilo que otorgó al día siguiente el cuatro de agosto de 1626, en él nos dice:

... Declaro que a don francisco de santíesteban vezíno y rregidor desta ciudad le debo doscientos rreales y una vara larga de trigo que me presto mando que se le pague. Declaro que don gonçalo chacon de rrojas presvitero vezino desta ciudad ha dado al dho otorgante seís fanegas de trigo a quenta de Pintura que le a de Hazer y el es deudor de las dhas seis fanegas de trigo al dho don gonçalo mando se le Paguen.

Declaro $q$ ue al padre fra Juan de guiruela de la orden de nuestra sra de la victoria le deve cinquenta rreales que le dio a quenta de pintura mando se le paguen.

Declaro que para el maestro fray jorge durango de la orden de ntr. sra del carmen tengo dos quadros de dos birgenes y les falta Poco Para acavarlos de todo punto y por quenta dellos e rrecibido cinquenta rreales...

...mando a Boifacio de Roxas el bastidor sobre que pinta el dho antonío mohedano... ${ }^{62}$

Damos aquí por concluido este trabajo sobre el circulo artístico antequerano del último cuarto del siglo XVI. Confiamos que en un futuro próximo podamos ampliarlo, dando nuevas noticias inéditas de éstos y de otros artistas que trabajaron y dejaron su obra en esta ciudad de Antequera. Lamentablemente de toda esta serie de obras documentadas pocas se conservan hoy día, pero sin embargo hemos creído necesario el facilitar y dar conocimiento de ellas aportando las detalladísimas descripciones que los contratos nos ofrecen. La interpretación y valoración de las obras quedan ahora para el crítico en arte.

${ }_{61}$ A.H.M.A.-F.P.N. Escribano Bartolomé González Porras, legajo 1.391, folios 972r a 975r.

62 A.H.M.A.-F.P.N. Escribano Bartolome González Porras, legajo 1.391, folios $975 v$ a $976 \mathrm{r}$ 
José Escalante Jiménez

Sin duda se está abriendo en Antequera un desconocido capítulo dentro de la historia del arte, que los especialistas estudiarán pausadamente en un futuro. La actividad creadora en el último cuarto del siglo XVI debió de ser abrumadora en la ciudad de Antequera, aspecto este totalmente ignorado hasta hace escasas fechas.

Confiamos que en breve todos estos datos sean analizados valorando en su justa medida la importante aportación antequerana a la creación artística en Andalucía.

\section{APENDICE DOCUMENTAL}

Documento $\mathrm{n}^{\circ} 1$

ESCRIBANO: ALONSO AGUILERA

LEGAJO: 437

FOLIOS: $644 \mathrm{r}$ a $645 \mathrm{v}$

FECHA: $1592-\mathrm{V}-6$

La capilla y hermanos de San Diego Escritura quontra antonio mohedano pintor.

En la ciudad de antequera en seis días del mes de mayo de míll e quinientos e noventa e dos años por ante mi alonso de aguilera escrivano publico y del numero de la dha ciudad por su magestad e los testigos aqui contenidos antonio mohedano vezino de la dha cibdad a quien doy fee que conozco de la una parte e Franco Ordoñez rretamal vezino della que ansimismo conozco en nombre de la cofradía y ermandad del glorioso $e$ bienabenturado san diego questa y empieza En el conbento de san francisco desta ciudad de la otra dixeron estar conbenidos E concertados y en mi presensia se concertaron $e$ habinieron en que el dho antonio mohedano a de píntar a lo fresco una capilla que se haze en el dho conbento de sr San franc ${ }^{\circ}$ para que en ella este el glorioso san diego e la dha su cofradía de la forma e orden que adelante se continua ymprebiniendo cerca dello Lo que le (... ) Por tanto por el tenor de la presente el dho antonio mohedano se obligo de pintar la dha capilla a lo fresco Los guecos de los quatro arcos hasta el suelo e sí sele pidiere que en la frontera donde ha destar el altar haga la misma pintura la ha de hazer de forma quede adornada con toda perfecion La dha portada y acerca de las ymaxenes y pinturas e lo demas que a de pintar e hazer en ella a de guardar El orden de dos trazas que quedan en su poder La una dellas firmada de domingo de cordoba vezino desta ciudad $e$ del dho antonio mohedano E la otra de mi el dho Escrivano y del dho antonio mohedano sin le ceder dellas en esa orden cosa alguna e a de comenzar la dha pintura Luego que la capilla este para ello e no a de alzar la mano hasta que anefecto la haya acabado con que precisamente a destar acabada El día de san miguel de setiembre prosimo deste presente año La qual dha pintura a de estar a contento del dho domingo de cordoba por rrazon della el dho Fco. ordoñez se oblígo en nombre de la dha cofradía le a de dar e pagar cien ducados...

Actua como testígo en la firma de la escritura Francisco Gutiérrez, alvañil. 
Escultores y pintores del círculo antequerano del XVI. Aportaciones...

\author{
Documento $n^{\circ} 2$ \\ ESCRIBANO: DIEGO DE CARVAJAL \\ LEGAJO: 1.908
}

FOLIOS: $324 \mathrm{r}$ a $325 \mathrm{v}$

FECHA: 1594-XII-16

juan de merodio escritura q. antonio de mohedano

Sepan quantos esta carta vieren como en la muy noble ciudad de antequera diez $e$ seis días del mes de díziembre Ano del nazimíento de nuestro Salvador jesuxpto de mill e quinientos e nobenta y quatro años en pressencia de mi diego de carvajal escrívano de su magestad e publico del numero de la dha ciudad e de los testigos aqui quontenidos parecieron presentes juan de merodio escrivano publico del numero de la dha ciudad y antonio mohedano de la gutierra maestro de pintura becinos della a los quales do fe que conosco dixeron que sean convenido que el dho antonio mohedano bende y se obliga de entregar al dho juan de merodio o a quien por el oviere de aver çínco quadros depintura en líenço con sus guarníciones dorados hechos de mano del dho antonío mohedano los quales ande ser de vara y quarto de alto y una bara de ancho y el uno a de ser de la encarnacion de nuestro sr. otro de la açuncion de nra. senora otro de santa maria madalena elevada otro de santa catalína y otro de san francisco Los quales an de ser fechos e acavados en perfecion e los dorados e molduras de los dhos quadros a de ser como otros que el dho juan de merodio tiene $Y$ ansi mismo se oblígo de dorar un quadro de un christo quel dho joan de merodio tiene todo lo qual el dho antonio mohedano se obligo de dar y entregar al dho juan de merodio fecho e acavado en perfecion...

PRECIO TOTAL: 60 DUCADOS

\author{
Documento n. ${ }^{\circ} 3$ \\ ESCRIBANO: JUAN DE MERODIO \\ LEGAJO: 708 \\ FOLIOS: $853 \mathrm{v}$ a $855 \mathrm{r}$ \\ FECHA: $1598-\mathrm{VI}-18$
}

EL SR. D. LOPE DE AREBALO SCRIPTURA Q. ANTONIO MOHEDANO

En la muy noble ciudad de antequera en diez y ocho días del mes de junio de mill y quinientos noventa y ocho años por ante mi juan de merodio scrivano del rrey nuestro señor y publico del numero desta ciudad e de los scriptos aqui contenidos parecio el sr, Don lope Arebalo del concejo del rrey nuestro señor e su regente en el rreal de navarra como marido y conjunta presensía ques de doña juana de Segura su muger vezinos desta dha Ciudad De lo que po rquanto Juan de l apuebla tio de la dha doña juana de segura su muger por su testamento que hizo cuya disposision murio mando que de sus bienes se sacasen y tomasen cien ducados para hazer un rretablo en la capilla que tenia y dejo en la yglesia mayor desta ciudad... (en estas líneas no transcrítas hay parte que estan perdidas hacia el margen izquierdo).

... pintor vezíno desta ciudad questa presente de que haga el dho rretablo para la dha capilla en los dhos cien ducados en la forma siguiente el retablo y quadro que sea de 


\section{José Escalante Jiménez}

hazer A de tener de gueco en alto tres varas e una quarta y de ancho dos varas y dos tercias pintado de pintura al olio en liencio e la guarnicion A de tener de madera una quarta de ancho en forma de alquitrave dada de negro e dorado y en el quadro a de yr pintado La transfiguracion de cristo en el monte tavor con las figuras del tamaño de altura ques cristo en una gloria con los dos profetas e Abajo los tres dicípulos en la sima del monte y en la guarnicion A de yr un letrero en que diga este altar y capilla del comendador gonçalo de la puebla y de sus herederos y sucesores e con dos tarjetas pequeñas en los angulos en la parte de abajo.

el qual dha rretablo lo A de haxer el dho antonio mohedano dentro de un año que a de correr desde el día de San juan primero deste presente mes y año...

\section{Documento n. ${ }^{\circ} 4$}

ESCRIBANO: JUAN DE MERODIO LEGAJO: 708

FOLIOS: $992 \mathrm{r}$ a $994 \mathrm{v}$

FECHA: 1598 -VII-15

Antonio mohedano escriptura que le otorgaron don lorenço de padilla y su hermana.

Folio $992 r$

En la muy noble ciudad de Antequera quínze días del mes de julio de mill y quinientos $e$ noventa e ocho años por ante my Juan de merodio escribano del rrey nuestro sseñor $E$ publico en el numero desta ciudad $Y$ de los testigos aquí contenidos parecieron don Loreço de padilla naxera $Y$ doña clara pacheco su hermana biuda muger que fue del contador diego de arze difunto vesinos en esta dha ciudad A quien doy fee que conozco e dixeron que por quanto Antonio mohedano de la gutierra pintor vezíno desta dha ciudad tomo Assiento y concierto con el

Licenciado Bartolome

(Perdido) herrero vicario de la yglesia

“ mayor de la billa de lucena $Y$ con los

ficíados sres xptobal sañudo

“ presbiteros curas

“ de la dha yglesía

“ como capellanes

“ para dorar y pintar

“ un rretablo de san mateo

“ billa de Lucena con ciertas

“ ontenidad y espresa

“ sierto quento

hicieron sobre

“ escriptura En

“ de tres años

“ en el día de SAn

“ pasado deste año

" mohedano 


\title{
Escultores y pintores del círculo antequerano del XVI. Aportaciones...
}

\section{Folio $992 v$}

pinte dore y estofe el dho rretablo y el dho bicario y beneficíado e con comissín del doctor Andres de rueda rrico probisor y bicario general en cordoba y su obispado por su señoria don francísco, de rreynoso obispo de la dha ciudad de cordoba del concejo del rrey nuestro señor se obligaron y obligaron sus bines de la fabrica A pagar al dho Antonio mohedano el dho rretablo por tasacion de oficiales e para que vaya haciendo el dho rretablo obligaron los bienes de las dhas fabrícas A que daran al dho Antonio mohedano en cada un año de los dhos rretablo quinientos ducados conque el dho Antonio mohedano haga En cada año con los dhos quinientos ducados que se le dieren...

\author{
Documento n. ${ }^{\circ} 5$ \\ ESCRIBANO: ALONSO DE AGUILERA \\ LEGAJO: 944 \\ FOLIOS: $413 \mathrm{r}$ a $415 \mathrm{v}$ \\ FECHA: $1577-111-18$
}

El rracionero Juan de aguilar scriptura $\mathrm{q}^{\mathrm{a}}$ diego de vega entallador

En la muy noBle ciudad de antequera diez e ocho días del mes de março de myll y quínientos y setenta y siete años en presencia de my El scrivano publíco e testigos Aquí presentes diego de Vega Entallador como principal e martin benytes tinagero e juan Alcayde sus fiadores vezinos desta dha ciudad...

... El dho diego de vega esta convenido e concertado con el sr. Rracionero juan de aguilar vezino desta dha ciudad de hacer un rretablo para La capilla que el dho señor Racionero tiene en la yglesia mayor desta ciudad de la forma y manera que adelante yra declarado dentro de año e medio que a de començar a açer desde El día de pasqua florida primero que vendra deste dho año que se contaran siete días del mes de abril por el senor rracionero le de e pague ciento e veinte y quatro ducados En Reales como fuere haciendo La obra del dho Retablo.. .

... El dho diego de vega como principal e los dhos martin benytez e juan Alcayde sus fiadores se obligaron de hazer e dar hecho El dho Retablo dentro del dho año y medio Asentado en la dha capilla El qual A de ser de la forma y manera siguiente Primeramente que El dho Retablo A de ser de madera de borne sin que yntervenga otro genero demadera Alguna $E$ lo a de dar segun es dho dentro del dho termino de talla y escultura y alquitítura $y$ ensamblaje e con condicion que a de tener el dho Retablo tres varas en ancho y cinco en alto Antes mas que menos que salga en proprocion Repartidos en nueve tableros en tres en tres con un Remate que lo ara de un frontispicio y una Resurecion Encima y los dhos nueve tableros An de ser de escultura de medio rrelieve de las ymagines siguientes La primera ymagen de los tres tableros Abra de ser de señor San Bartolome y la de enmedio de los dhos tableros abra de ser un crucffixo con san juan e nuestra señora y la madalena Al pie de la Cruz Y la otra imagen del tercero tablero a de ser de señor san miguel e del primer tablero de la hilada de enmedio A de tener una ymagen de señora santa catalina y en el tablero de enmedio de la dha hilada A de tener otra ymagen de la porificacion de nuestra señora y en el tercero tablero otra ymagen de santa Lucía y en los tableros altos del dho Retablo el primero A de llevar La ymagen del crucifixo tendida la Cruz en el suelo que lo esten crucificando 
José Escalante Jiménez

y el segundo tablero a de ser la mysma ymagen quando llevava La cruz a cuestas y en el terzero tablero La mysma ymagen Atado A la coluna quando lo açotaron los sayones A los lados que es de la forma questan señalados en un modelo que esta en poder del dho señor Racionero firmado de su nombre e del dho díego de vega e de my el dho scrivano $Y$ con condicion que en La medía Luna A de llevar un espiritu Santo e doze colunas rrevestídas de follaxe e unas carones e colgamenas e sus capiteles conposidos de la mejor orden e quefueren mas (. ?.) que se pudiere hazer y las coronaciones de los dhos tableros an de ser de cartones con un serafin en medio por atapre y en los frisos unos niños con otros de cartones con otro Atapre en medio En las entre vasas de los rresaltes Unas medallas o serafines y en los Remates arriba del Retablo de las dos ordenes cabezas de veneras por coronacion En la una parte y en otra y encima de las veneras por rremates dos xarras en cada una La misma y en las esquinas del Remate del rretablo dos nyños desnudos o vestidos de las ynsignyas de la pasion de xpto y con condicion que a de llevar por aconpañamiento del dho Retablo un frison lleno defollaxe y frutas e unos nyños que vayan rrepartidos por el dho follaxe Alcançando las dhas frutas...

\author{
Documento n. ${ }^{\circ} 6$ \\ ESCRIBANO: BENITO SÁNCHEZ HERRERA \\ LEGAJO: 1.333 \\ FOLIOS: $721 \mathrm{r}$ a $721 \mathrm{v}$
}

FECHA: 1592-II-24

Andres de Yriarte e Joan de Leon belmonte scriptura entre ellos

En la ciudad de antequera en veinte e quatro días del mes de febrero de mill e quinientos e noventa e dos años por ante de mi benito sanchez de herrera escrivano del rrey nro sr y Publico en el numero desta dha ciudad e de los testígos yuso scríptos Andres de yríarte vezino desta dha cibdad de la una parte e en la otra joan de leon belmonte vezino della díxeron estar convenidos e concertados e por la presente se convinieron e concertaron en esta manera que el susodho Andres de Yriarte a de ser obligado y se obligo de hazer al sobre dho una figura de un xpto Resucitado de dos varas de alto de pino dorado y gravado bien hecho y a contento del dho joan de Leon e se obligo de darlo hecho la semana santa primera que viene...

... E que si dentro de un año se Abriere sea obligado e se obligo el dho Andres de Yriarte A lo rreparar a su costa e lo a de dar encarnado $Y$ acabado de todo punto...

\title{
Documento n. $^{\circ} 7$
}

ESCRIBANO: DIEGO DE CARVAJAL

LEGAJO: 1.908

FOLIOS: $351 \mathrm{r}$ a $352 \mathrm{v}$

FECHA: 1594-VIII-23

Juan lopez melero scriptura contra andres de ydiarte

... de la una parte joan Lopez melero çapatero e de la otra andres de idíarte escultor como príncipal e joan diez calderero como su fiador.. 


\section{Escultores y pintores del círculo antequerano del XVI. Aportaciones...}

... díxeron que se an convenido e concertado quel dho andres de idiarte a de hacer para el dho juan Lopez una ymaxen de christo crucificado muerto desiete quartas destatura e nproporcion con su crus e calvario y la estatua a de ser de madera de alamo o de peral y la cruz de pino $Y$ de los pies avaxo La cruz a de tener otras siete quartas y el calvario a de ser conpetente $Y$ todo ello a de ser de madera seca $Y$ bien sasonada y acavado En perfecion $Y$ de las calidades dhas...

\section{Documento $\mathrm{n}^{\circ} 8$ \\ ESCRIBANO: BARTOLOMÉ DE PORRAS}

LEGAJO: 1.127

FOLIOS: $811 \mathrm{v}$ a $812 \mathrm{r}$

FECHA: $1595-$ VII-3

Diego bastardo y Luis de La Haya

En la muy noble ciudad de antequera En tres dias del mes de julio de mill e quinientos E noventa E cinco años en presencia de my bartolome de porras escrivano de su magestad e publico del numero desta dha ciudad e de los testigos aqui contenidos parecio Luís de la haya escultor vezino desta ciudad e dixo que se obligaba y obligo de hazer para diego bastardo vezino de la ciudad de malaga Una hechura de san juan evangelista de madera que tenga de alto Con la peana siete quartas y se lo dara y en tregara en toda perfecion e de madera buena puesta en esta ciudad de antequera en casa del dho otorgante en todo el mes de agosto prosimo venydero deste presente año de la fecha desta scritura y a contento del dho diego bastardo y por El le a dedar E pagar al dho veynte y dos ducados...

\section{Documento n. ${ }^{\circ} 9$ \\ ESCRIBANO: ALONSO DE AGUILERA}

LEGAJO: 922

FOLIOS: $739 \mathrm{v}$ a $742 \mathrm{r}$

FECHA: 1580 -VII-29

Benyto sanchez e nycolas Ruiz escritura $\mathrm{q}^{\mathrm{a}}$ Luis fernandez pintor

En la ciudad de antequera a veynte y nuebe días del mes d ejulio de myll e quinientos ochenta años En presencia de mí El escrivano publíco y testigos de yuso Escritos luys fernandez pintor vezino desta dha ciudad a quien yo El dho Escrivano doy fe que conozco dixo que por quanto El y gabríel de la freyla Ensanblador vezino de la ciudad de granada se conbíníeron y concertaron con beníto, sanchez de la sercas y con nicolas ruyz su tio vezínos Desta ciudad y en su nombre con fray francisco de la orden de nuestra senora de jesus frayle del monasterio que de la dho orden ay En esta ciudad de les hazer Un rretablo dentro de cierto tiempo que se cumplio el día de santiago del ano pasado de myll e quinientos y setenta y nuebe años que abia de tener catorze quartas de alto dende El banco hasta la postrera corniza y diez quartas de ancho con seys tableros dibididos En tres calles y en los dos tableros de enmedio avia de llebar dos ystorias de medio rreliebe la Una un cristo cruzificado con nuestra señora y san juan a los lados y la otra del parto de santana doradas y estofadas y en las otras dos 


\section{José Escalante Jiménez}

calles de los lados avian de yr pintados en el un tablero la limpia concecíon de nuestra señora $y$ en el otro san juan Bautista y en el otro el angel Sal; myguel y en el otro santa catalina $y$ todos los frisos y colunas dorados $Y$ estofados En los lugares que les conbinyese y en los rremates de las dhas tres calles avian de yr pintados de pincel En el de en medio un dios padre y en el de un lado una santa con una rrosa en la mano y en el otro santa clara y en los tableros del banco en el tablero de en medio pintada la madalena y en un tablero de los lados santo anton y en el otro Santa quiteria y que lo abían de dar hecha y acabado En toda perfecion A contento del dho fray francisco y de andres bela clerigo vezinos desta ciudad que si dentro del dho termino no lo diesen acabado de la forma questa dho que a su costa lo pudiesen hazer y les executasen por cinquenta y ocho ducados En que se abia conzertado e por lo que tubiesen rrecibido y por mas lo que El dho rretablo les costase y para En quenta de los dhos cinquenta y ocho ducados los dhos benyto sanchez y nicolas rruyz y el dho fray francísco en su nombre les avian dado e pagado los quarenta ducados dellos por no aver hecha El dho rretablo En el tiempo en que se oblígaron el dho día parescío ante la justicía deta ciudad el dho nículas ruyz por sí y en nombre del dho Benyto SAnchez e presento un pedimiento En que pidio que el dho luis fernandez Jurase y declarase sí hera berdad que el y el dho gabriel de lafreyle se abian conbenido y conzertado con El y con El dho benyto sanchez de hazer El dho rretablo de la forma que esta dho y declarado en precio de los dichos cinquenta y ocho ducados y que para en quenta dellos tenían rreseibidos los quarenta y por la dha justícia fue mandado El dho luys fernandez lo declarase y abiendo declarado ser verdad todo lo susodho por la dha justicía fue rreseibído juramento y En todo el día daría contento sobre El dho rretablo A los dhos nycuelas rruyz y benito sanchez o que se yria a la carzel y se entregaría por preso al alcayde della y que no saldría de la dha prision sin licencia del juez conpetente so pena que se procediera contra el como todo lo suso dho consta e pareze por los au tos que queda en my poder de que doy fe y agora sea conbenído y conzertado con El dho nicolas rruyz y con el dho benyto,sanchez de hazer y acabar El dho rretablo dentro de quatro meses cumplidos primeros siguientes que corren y se quentan desde el dho día en toda perfícion y acontento de los dhos fray francisco y andres bela de la forma que estaba tratado y conzertado y en esta Escritura se contiene contanto, que las dos ystorias que abia de llebar En los dos tableros de la calle de enmedio es el cristo cruzificado con nuestra senora y san juan a los lados y el parto de santana como abían de ser de medio rrelíebe a de ser hecha y pintado de pinzel como en las demas ymajineria que el dho rretablo a de llebar esso por quanto los dhos beníto sanchez y nículas ruyz le dieron y acrecentaron de mas de los dhos cinquenta y ocho ducados otros ocho ducados mas que son por todos sesenta y seis ducados de los quales demas de los dhos quarenta ducados que el y el dho gabriel de la freyla tenían rreseibídos le an dado e pagado otros treze ducados y treze ducados que se le rrestan debiendo El dho niculas rruyz se los a de dar e pagar como lo fuere hazíendo.

\section{Documento $\mathrm{n}^{\circ} 10$ \\ ESCRMANO: DIEGO DE CARVAJAL}

LEGAJO: 1.868

FOLIOS: $274 \mathrm{r}$ a $277 \mathrm{v}$

FECHA: 1586-VIII-21

Leonor de la torre biuda y Juan de montes spcritura entrellos 
Sepan quantos esta carta vieren como en la muy noble ciudad de antequera a veyntiun días del mes de agosto año del nacimiento de nuestro salvador jesu xpto de myll y quinientos ochenta y seis años en presencia de mi diego de carvajal scrivano de su magestad publico en el numero de la dha ciudad y de los testigos aqui contenidos Parecieron pressentes de la una parte Leonor de la torre biuda muger que fue de alonso nyeto difunto vezina desta ciudad y de la otra Juan de montes flamenco escultor estante En ella y dixeron que por quanto la dha leonor de la Torre para el ornato de una capilla que tiene en el nionasterio de sant agustin desta chidad a de hazer un rretablo y se a convenido con el dhojuan de montes de quel suso dho lo haga y pinte y dore y acabe en perfecion y lo asiente el; la dha capilla sobre el altar que en ella esta flio y el dhojuan de montes lo a aceptado y se obliga a lo hacer y acabar en perfection como en lo que toca a la escultura y arquitectura como En lo que toca a la pintura y dorado y a de poner toda la madera oro e matizes que fueren necesarios asta lo asentar en la dha capilla...

... el dho juan de montes se obligo de hazer conforme a la traça y modelo que para ello dio la qual esta dibuxada en papel y firmada al pie del dellas firma y nombres de los dhos otorgantes dentro de diez meses cumplidos...

... y en el hazer el dho rretablo y acabarlo a de guardar y cumplir las condiciones siguientes. que toda la madera del dho rretablo ansi de los rrelieves y figuras de bulto como la de los tableros a de ser de Pino seca y bien acondicionada sin nudos bien labrada y encaxada como fuere nescerario para que la dha obra este puesta y acabada en perfection y los tableros y las demas pieças del dho rretablo que fieren nescesarias an de estar bien encoladas y ennervadas de manera que no se abran ni hagan grieta ni hendedura quel dho rretablo A de ser de altura de treze tercias y de ancho diez tercias poco mas o menos como convenga para la buena medida de la arquitectura y las dhas treze tercias de altura a de tener desde la punta de frontís hasta el asyento del banco y las dhas diez tercias de anchura A de tener el dho banco poco mas o menos y todo A de yr conforme a la dha traça y modelo questa rreferido y a los Lados del altar a de tener dos mensillas de madera en que aguante el dho rretablo lo que fuere mayor quel dho altar que la Primera orden de colunas A deser jonícas $Y$ la segunda orden a de ser de colunas corintias y todas redondas y estriadas. en el Primero querpo en el medio a de llevar una ymagen de nuestra señora con un niño En los braços y a destar en pie de bulto rredondo con un vestido y rropaje a lo greciano $Y$ en los tableros questan a los lados en el primer querpo A de tener Las figuras de San juan bautista a la derecha y la de santo antonío de paula a la sinyestra los quales an de ser de pinzel. En el tablero del cuerpo segundo a destar de pinzel la demostracion de la Santísima trinidad con lo se mostrara por una estampa que la dha leonor de la torre a de dar al dho juan de montes. La tarja questa encima del dho tablero Y las veneras questan encima de los tableros del primero querpo y las dos figuras de samt pedro y sant pablo que an de yr por rremate Encima del primero cuerpo An de ser de rrelieves y las dhas dos figuras de rrelieve entero. quel banco del dho rretablo en Los compartimientos del En Los dos pedestales ultimos A de llevar dos tarjas de pinzel con blasones de armas y en el medio la figura de la magdalena en el acto de la penitencia $Y$ en los pedestales del medio dos medallas de las fíguras de santa catalina y santa litzia martires $Y$ en los otros dos compartimyentos debaxo de los tableros a la derecha el nacimiento de nuestra señora ya a la syniestra La fígura de santo ylefonso que rrecivio la cazulla de mano de nuestra señora todo lo qual y los demas tableros del dho rretablo an de ser de pínzel al olio de tan buena mano como esta el rretablo de alonso gomez 


\title{
José Escalante Jiménez
}

escrivano publico En la yglesía de san sebastían. que todos los relieves y figuras de bulto del dho rretablo y la arquitetura del a de ser dorado de oro bruñido y los festones y tarjas y figuras de bulto estofados quencima del frontispício del dho rretablo a de llevar sus rremates torneados y galanos del grandor que fueren necesarios conforpue a la disposicion de la capilla los quales an de ser de la forma que fueren mas curiosos...

\author{
Documento n. ${ }^{\circ} 11$ \\ ESCRIBANO: BENITO SÁNCHEZ HERRERO \\ LEGAJO: 1.464 \\ FOLIO: $502 \mathrm{r}$ a $503 \mathrm{v}$ \\ FECHA: $1587-\mathrm{IV}-18$
}

Las condiciones conque sea de hazer El Retablo son las siguiente

Primeramente quel Retablo sea de dorar de oro bruñido todas las lunas salvo lo que no se pareciere y lo que cayere detras de las colunas a de yr de color salvo los agallones que ban por medio que las divide con una faxa de un dedo al rrededor de los dichos agallones. Es condícion que la cornisa y otras qualesquier molduras que En el dicho rretablo huviere an de yr doradas salvo Los Envejes de las coronas doquiera que se hallaren que an de ser de azul conforme a las del rretablo de gonçalo de leon. Es condicion que las beneras y festones del dicho rretablo an de yr dorados salvo las Estrías de las beneras que an de yr de color. Es condicion que en la caxa de nra señora ande yr los lados pintados de grotesco de colores y la frontera de azul y estrellas de oro. Es condicion que el liso questa Entre la coluna y rrequadro de nra. señora a de yr dorado liso y tambíen El rrequadro y en lo llano del gravado un rromano de azul y oro. Es condicion que En Un Espacio liso questa sobre El rrequadro de la caxa de nra señora ande yr pintados dos niños. Y es condicíon que los demas lugares lisos no declarados como Enxutas de arcos de baxo de los festones y llanos de frontispicios y lados del cuerpo alto del rretablo ande yr píntados de jaspe y todos los dichos lisos cercados de una faxeta de oro de una pulgada. Es condicion que la ymagen de Nra señora a de yr dorada y estofada la saya y toca y unas orillas En el manto y las otras dos figuras que van por rremates sobre El primer cuerpo tambien an de yr doradas sin ningun estofado. Es condicion que las Estrías y yntercolunios de las colunas del cuerpo alto ande yr de color y lo demas dorado conforme a lo declarado. Es condicion que los dos tableros del primero cuerpo an de yrpintados dos santos Encada tablero uno lo que quisieren de buena pintura. Es condicion que en el tablero de Enmedio del vanco sea de pintar de santos una madalena En la penitencia y en los quatro pedestales quatro medallas y en los dos tableros del vanco de los lados dos escudos de armas. Es condicion que los boljores de los arcos ande ser de jaspe con sus fajas de oro. Es condicíon que dicho rretablo lo tengo de dar acabado para fin de agosto deste presente año de 1587 por precío de cien ducados con las condiciones sobre dichas a contento de juan de montes escultor y de francisco gutierrez los quales mean de acudír con las pagas En la forma siguiente dies ducados Luego Ėn señal de la obra y treynta En començado y otros treynta como se fuere dorando o En estando dorado y los treynta despues de acabado acontento de los susodichos y no otra persona y por que ansí lo cumpliere lo firmo de mí mano fecho En 18 de abril de 1587 años

(Firma:Juan Vazquez de Vega) 
Escultores y pintores del círculo antequerano del XVI. Aportaciones...

dezimos juan de montes y fracogutierrez que aceptamos Estas condiciones En la forina sobredicha y por verdad Lo firmamos fecho En 18 de abril de 1587

(Firma:juan Montes Francisco Gutierrez)

en la muy noble ziudad de antequera en veinte e un días del mes de abril año de mill e quinientos y ochenta e siete anos en presencia de mi el scrivano publíco e testigos aquí contenidos parecio juan Vazquez de vega Pintor de ymagíneria vezino desta zibdad a quien doy fee que conozco y dixo que se obligaba y se obligo de Pintar e dorar El Retablo contenido En las condiciones desta otra scriptura y conforme a Ellas y a sus declaraciones

Documento n. ${ }^{\circ} 12$

ESCRIBANO: ALONSO DE AGUILERA

LEGAJO: 926

FOLIOS: 201r a $202 v$

FECHA: 1595-11-27

Los cofrades de San josepe Escritura q' $\mathrm{Al}^{\circ}$ quintero

En la ciudad de antequera en veynte e siete días del mes de febrero de mill e quiníentos E noventa e cinco años por ante mi alonso de aguilera scrivano publico del num ${ }^{o}$ desta dha ciudad e de los scríptos aqui contenidos joan de arnani y antonio de padilla e bartolome sanchez ballexo carpinteros vezínos de la dha ciudad de la una parte ermanos e cofrades de la ermandad del glorioso $Y$ bien abenturado san josehpe y al quintero pintor vezino della de La otra e dixeron que por quanto esta conbeiídos e concertados E por la presente se conciertan e conbienen en esta manera que el susodho $A l^{\circ}$ quintero se obligo de pintar La capilla del glorioso san josehpe questa en el conbento e monesterio del sr. San franc ${ }^{\circ}$ desta ciudad en esta forma quatro tableros y en cada uno dellos las ystorias que los dhos hermanos le pídieren al olio y la arquitectura que llebare a de ser por de dentro e por de fuera conforme a un modelo e traza que queda en poder del dho joan de arnani firmada de mí El dho scrivano al tenple y en lo alto de los artesones que ban dando buelta a ala de la dha capilla por la parte de adentro ha de pintar un dios padre y un coro de angeles con sus ynstrumentos de musica Lo qual de todas las figuras que a de pintar a de yr A olio de mas dello qual a de pintar en el lienzo de cortina que a de ir en la dha capilla un níno jesus y un san josehpe al temple y igualmente se obligo de hazer la dha pintura en toda perfecion de aqui al día de pasqua florida primero venídero deste presente año y a contento de gusto de antonio mohedano vezíno desta ciudad... 


\section{José Escalante Jiménez}

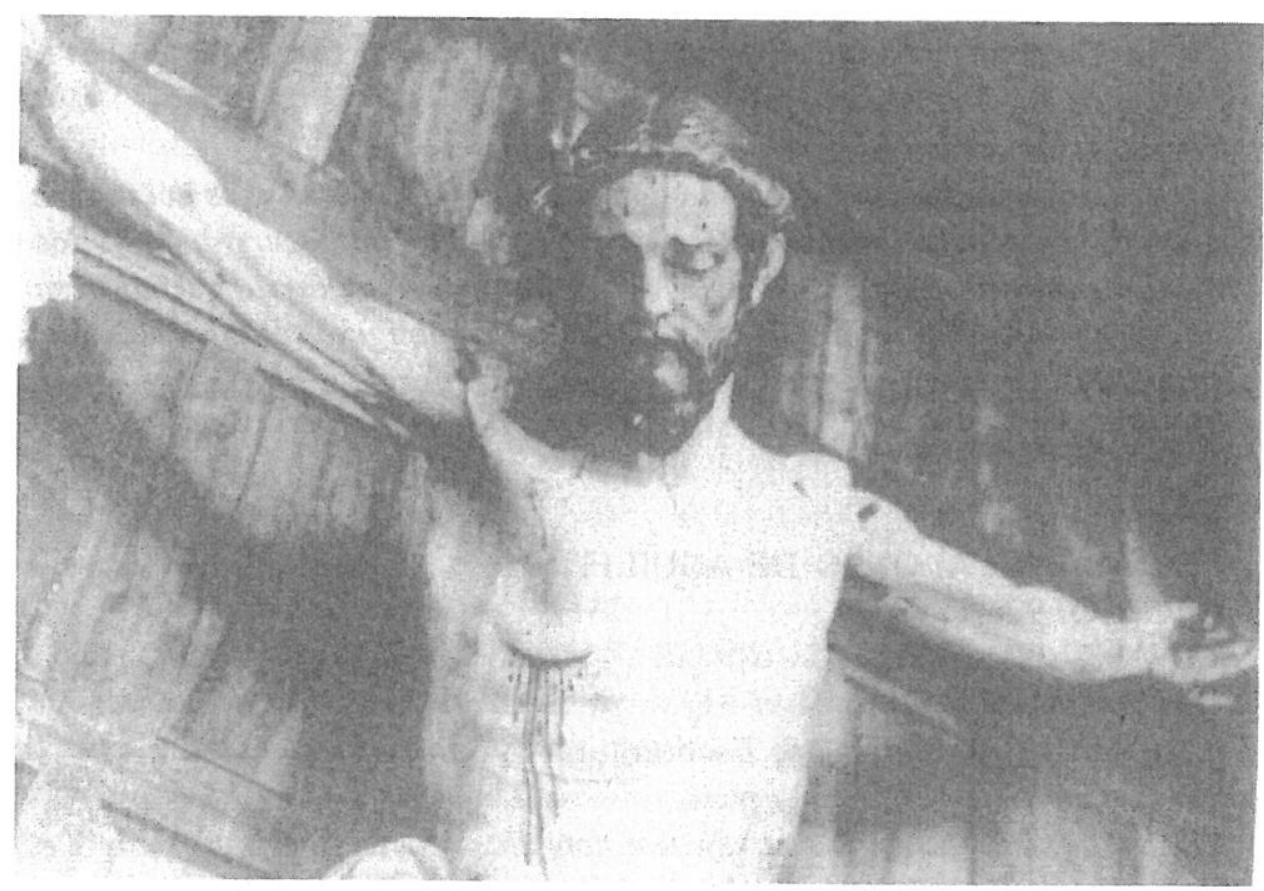

1.- Diego de Vega. Cristo Crucificado (1578). Parroquia de Santa Ana. Archidona

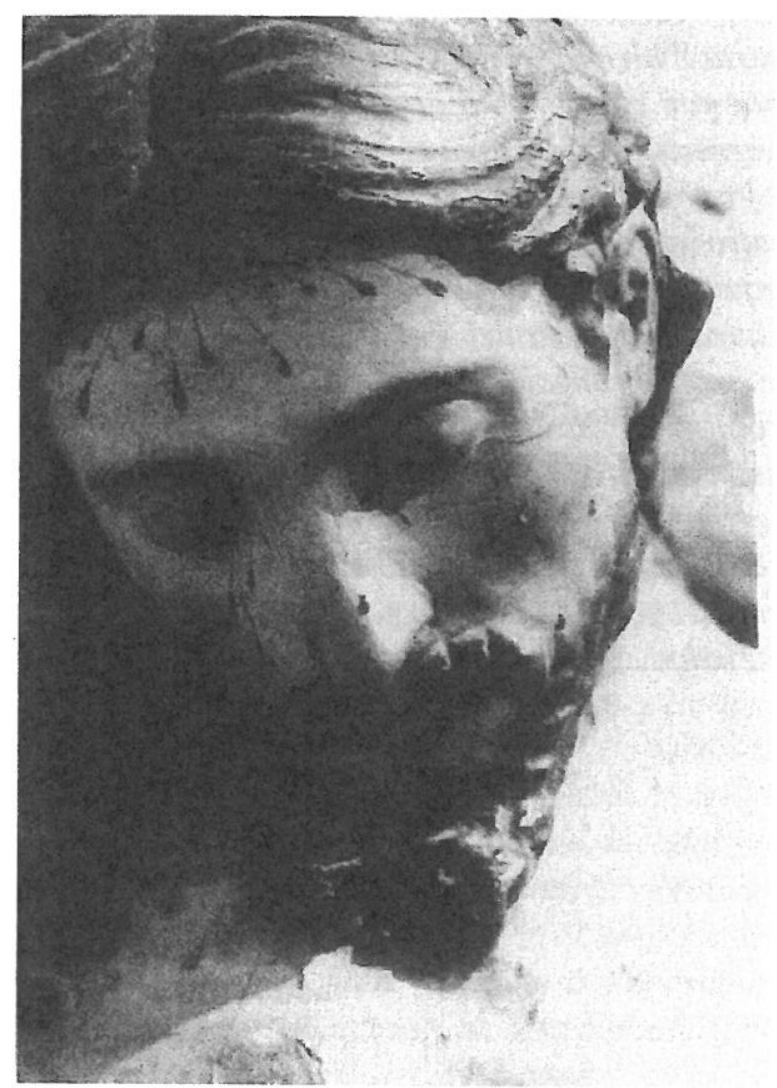

2.- José Hernández. Cristo de la Paz (1592). Iglesia del Carmen. Antquera (Detalle). 
Escultores y pintores del círculo antequerano del XVI. Aportaciones...

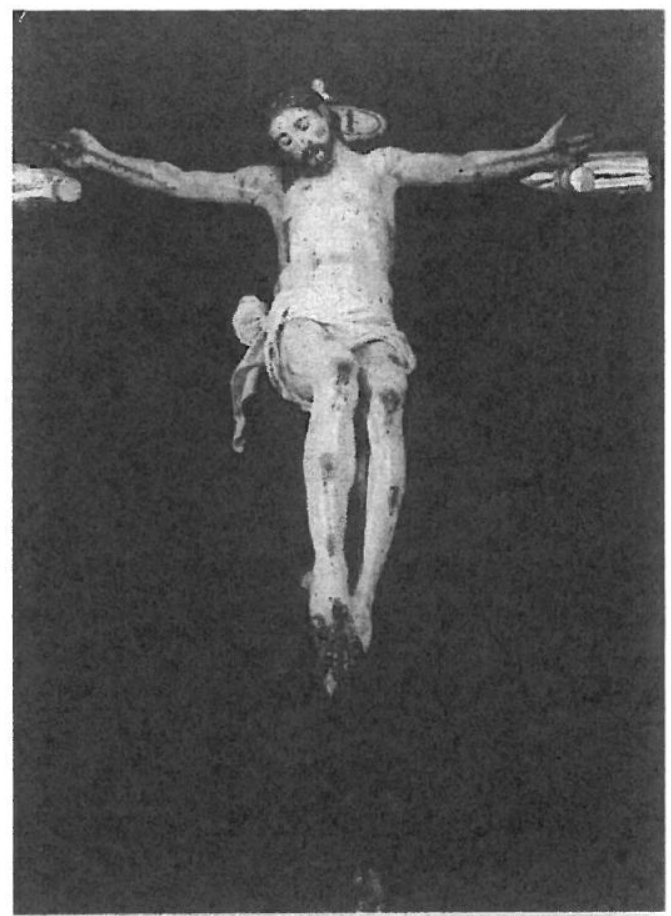

3.- José Hernández. Cristo de la Paz (1592). Iglesia del Carmen. Antequera.

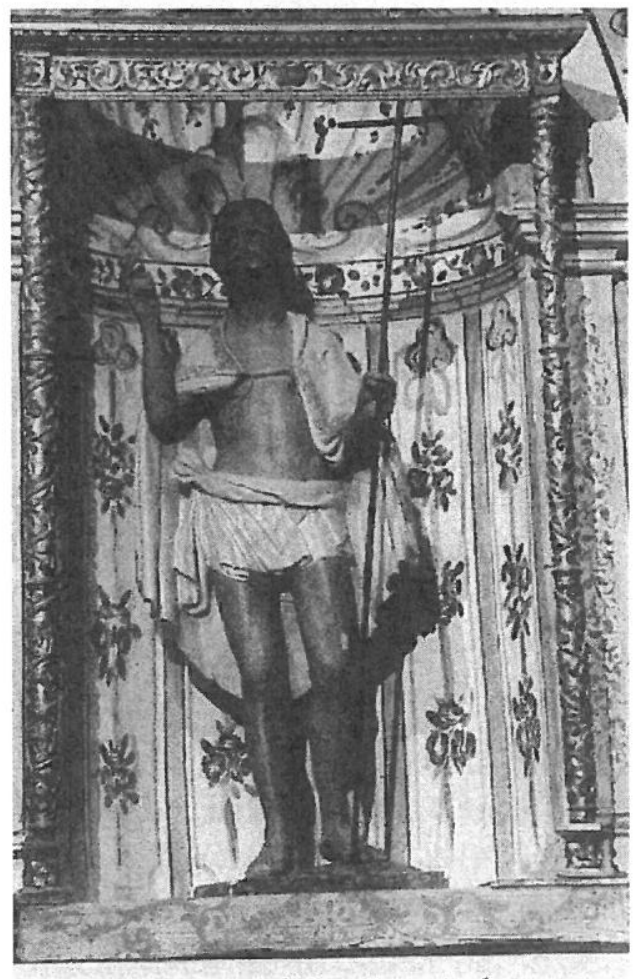

5.- Andrés de Iriarte. Cristo Resucitado (1592). Iglesia del Carmen. Antequera.

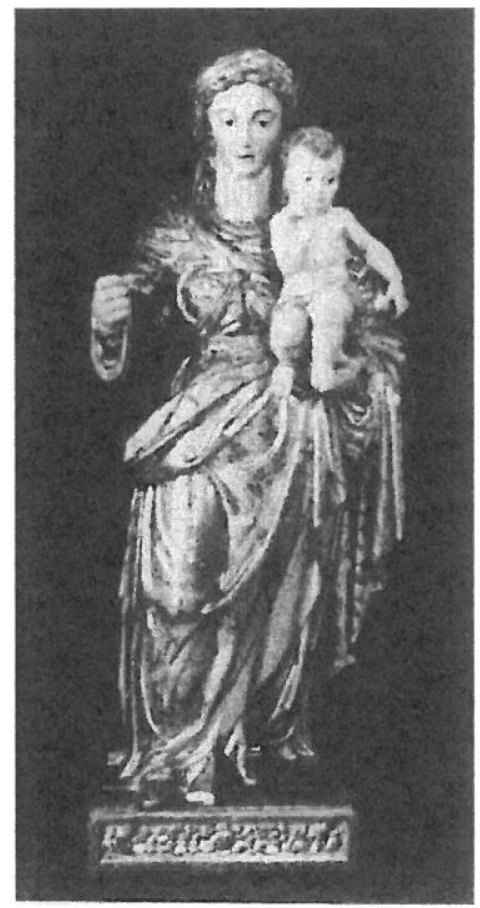

4.- Juan Vázquez de Vega. Virgen del Rosario (1587). Iglesia de Santo Domingo. Antequera.

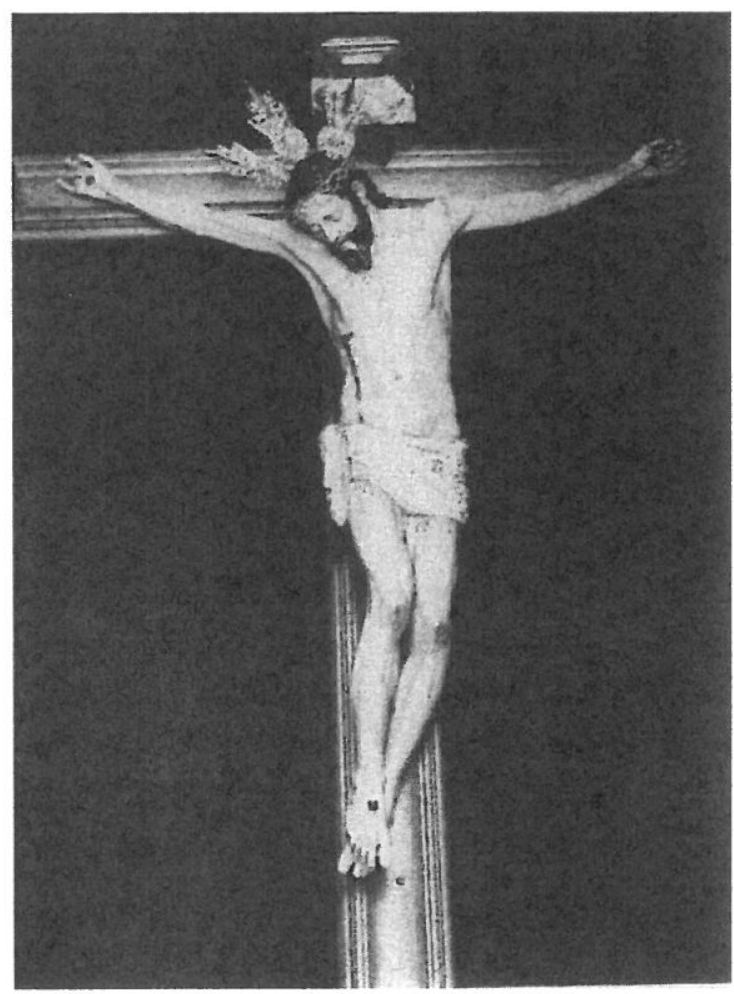

6.- Diego de Vega. Cristo de San Agustín (1582). Iglesia de Santo Domingo. Antequera. 
José Escalante Jiménez

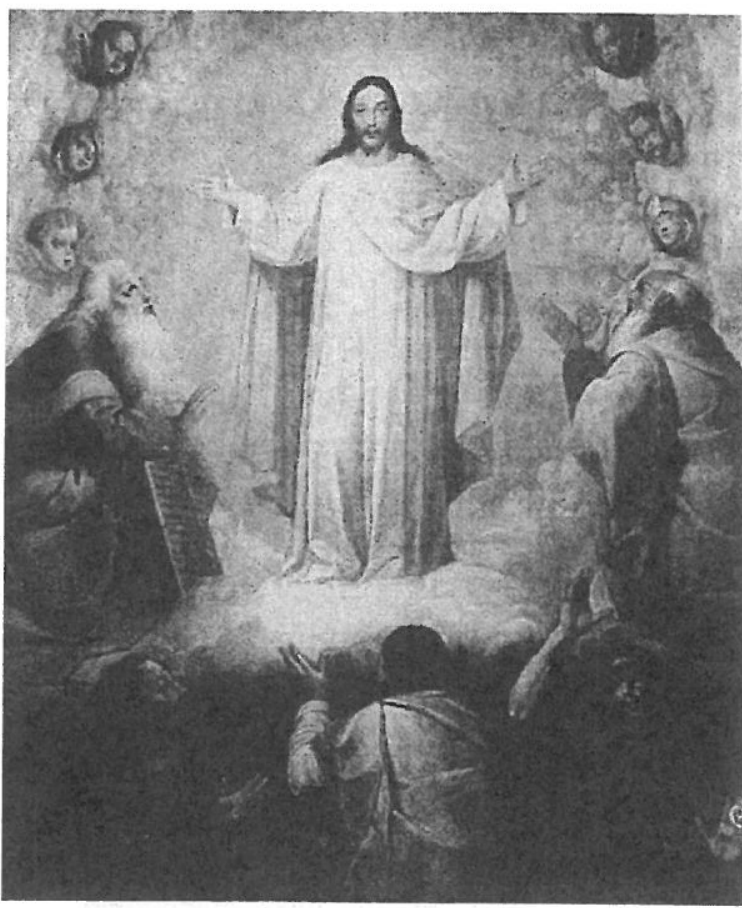

7.- Antonio Mohedano. Transfiguración de Cristo en el monte Tabor (1598). Colegiata de San Sebastián. Antequera.

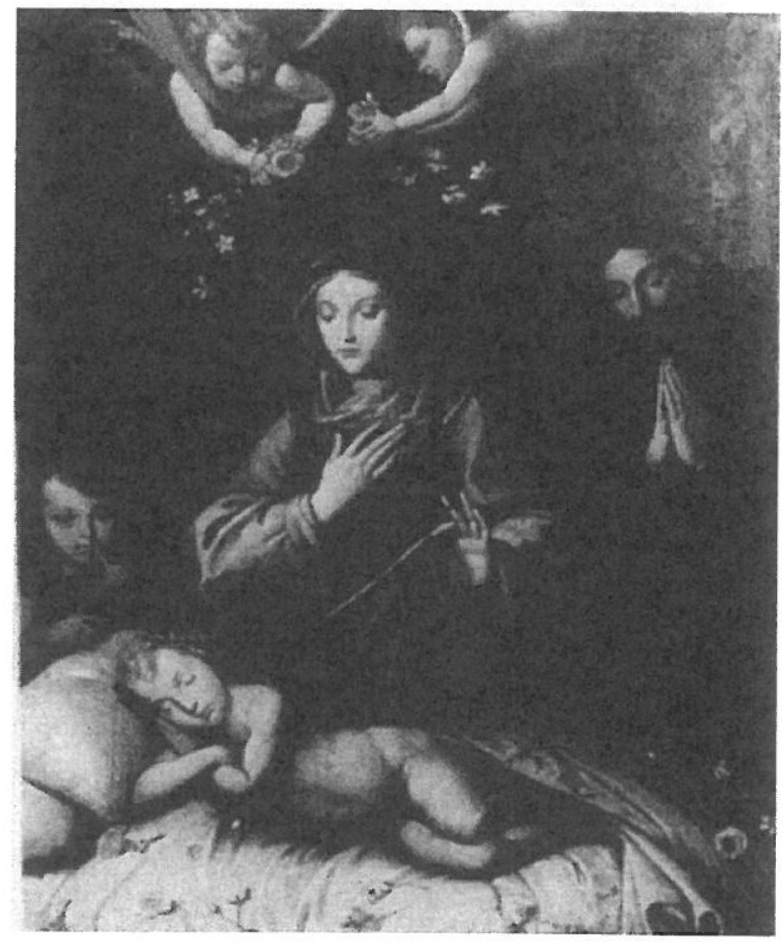

8.- Antonio Mohedano. Virgen del Silencio. Museo Municipal. Antequera.

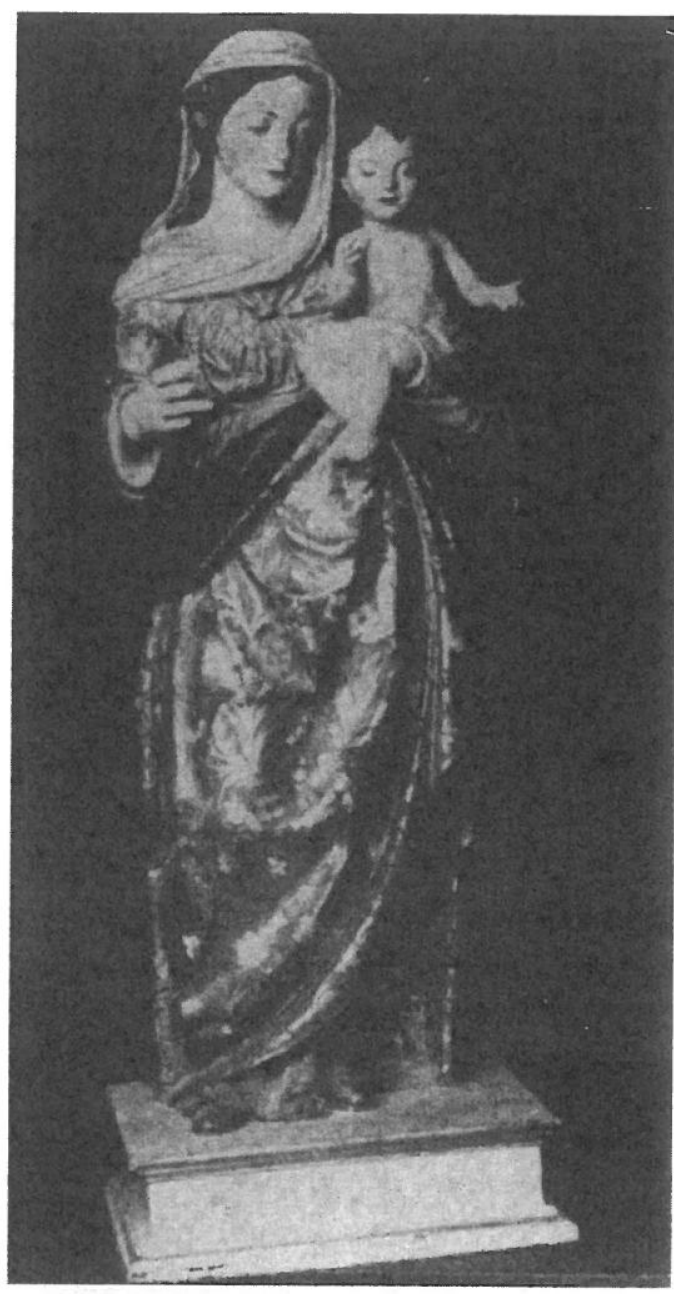

9.- Andrés de Iriarte. Virgen de Gracia (1600). Iglesia de los Remedios. Antequera. 